\title{
12. INTERHOLE CORRELATIONS AT SITE 893, SANTA BARBARA BASIN: CONSTRUCTION OF A 16,000-YEAR COMPOSITE RECORD USING MAGNETIC SUSCEPTIBILITY AND DIGITAL COLOR IMAGING DATA ${ }^{1}$
}

\author{
Frank R. Rack ${ }^{2}$ and Russell B. Merrill ${ }^{3}$
}

\begin{abstract}
Two independent sets of nearly continuous core measurements, comprising magnetic susceptibility and digital color data, were used to develop correlations between Holes 893A and 893B, located in the central Santa Barbara Basin. These data sets provide spatial (temporal) resolutions on the order of $\sim 5 \mathrm{~cm}(\sim 35 \mathrm{yr})$ for magnetic susceptibility measurements, and $\sim 1$ to $2 \mathrm{~cm}$ $(<7-14$ yr $)$ for digital color measurements averaged over 12 points.

These two data sets contain information about changing paleoenvironments and/or climatic signals at temporal scales approaching those provided by studies of ice cores, lake records, or coral growth for the past 160 ka (kilo-annum, or $1000 \mathrm{yr}$ before present). This potential makes it especially important that the age-depth relationship for these proposed proxy records is thoroughly investigated; especially considering the large amount of gas expansion encountered in the cores recovered from Site 893 (see gas-related void table in Merrill and Beck, this volume).

This manuscript first explores the continuity of the magnetic susceptibility and digital color data from Holes 893A and 893B by matching individual features observed in the records from each hole. Following this, we use the magnetic susceptibility data from the upper portion of these two holes to develop a spliced record for equivalent time intervals in each hole, from the sediment surface (approximating the present day) to approximately $16 \mathrm{ka}$, just after the Last Glacial Maximum.
\end{abstract}

\section{INTRODUCTION}

\section{Background and Previous Work}

An increasing number of paleoceanographic studies on Ocean Drilling Program and Deep Sea Drilling Project (ODP/DSDP) cores require the development and use of a consistent age-depth model between adjacent holes at a given site. Recent drilling legs with paleoceanographic objectives have demonstrated some of the available techniques and methodologies for constructing these composite records and have highlighted the scientific potential of these activities (Hagelberg et al., 1992, 1995; Mayer et al., 1993; Shackleton et al., 1995; Shackleton and Shipboard Scientific Party, 1992; among others).

Individual types of sensors have been long used to characterize the properties of whole-round sediment cores in terms of their magnetic susceptibility, bulk density (using the gamma-ray attenuation porosity evaluator, or GRAPE), and compressional wave velocity; however, new generations of core sensors are being developed and used, including sensors to measure light reflectance on split cores (Balsam and Deaton, 1991; Barranco et al., 1989; Deaton and Balsam, 1991; Mix et al., 1992, 1995) and natural gamma-ray emissions from whole-round cores (Miller, Mountain, Blum, et al., 1994). These techniques all provide data that can potentially be used as proxy records of changing depositional and/or paleoenvironmental processes that reflect local, regional or globally significant paleoceanographic and/or paleoclimatic changes. This study addresses

'Kennett, J.P., Baldauf, J.G., and Lyle, M. (Eds.), 1995. Proc. ODP, Sci. Results. 146 (Pt. 2); College Station, TX (Ocean Drilling Program).

Ocean Mapping Group, Department of Geodesy and Geomatics Engineering, University of New Brunswick, Fredericton, N.B., E3B 5A3, Canada.

Ocean Drilling Program, 1000 Discovery Drive, Texas A\&M Research Park, College Station, TX 77845-9547, U.S.A. two such records (i.e., magnetic susceptibility and digital color data) from Site 893.

\section{Site 893}

Site 893 is located at $34^{\circ} 17.25^{\prime} \mathrm{N}, 120^{\circ} 02.2^{\prime} \mathrm{W}$, on the floor of the Santa Barbara Basin, California, $20 \mathrm{~km}$ south of the Santa Barbara coastline at a water depth of $576.5 \mathrm{~m}$ (Kennett, Baldauf, et al., 1994; Fig. 1A). Two holes were drilled at this site; a total of 21 cores were recovered with the advanced hydraulic piston corer (APC) to a depth of $196.5 \mathrm{~m}$ below the seafloor (mbsf) at Hole 893A, and a total of 8 APC cores were recovered to a depth of $68.8 \mathrm{mbsf}$ at Hole 893B.

The sediments recovered at Site 893 are generally a mixture of terrigenous (clays, silty clays, and sands) and biogenic (carbonate and opal) materials. The primary long-term controls on sediment depositional processes in the Santa Barbara Basin are (1) changes in relative sea level (creating differences in basin geometry, ocean circulation patterns, and differences in sediment transport processes and pathways across/along the shelf and slope), and (2) changes in the rate or direction of tectonic motions (convergence across the Santa Barbara Channel and uplift of the Transverse and Coast Ranges, causing changes in the frequency or magnitude of earthquakes and changes in stream profiles/runoff patterns). Shorter time-scale controls on the preservation of sediment layers include: (1) vertical/lateral water mass migrations, (2) changing oxygen content of bottom waters, (3) relative changes in the intensity of bioturbation, (4) differences in the flux rate of biogenic and terrigenous inputs to the Santa Barbara Basin and, (5) other depositional and postdepositional processes.

This paper concentrates on the sediments recovered in the upper $24 \mathrm{mbsf}$ of the two holes at Site 893 (i.e., the intervals of overlapping coverage with laminated and massive sediment facies) in an attempt to identify the common correlative features in both holes. We will attempt to establish the degree of interhole continuity that individual sedimentary layers (i.e., gray beds) exhibit, based on their magnetic 

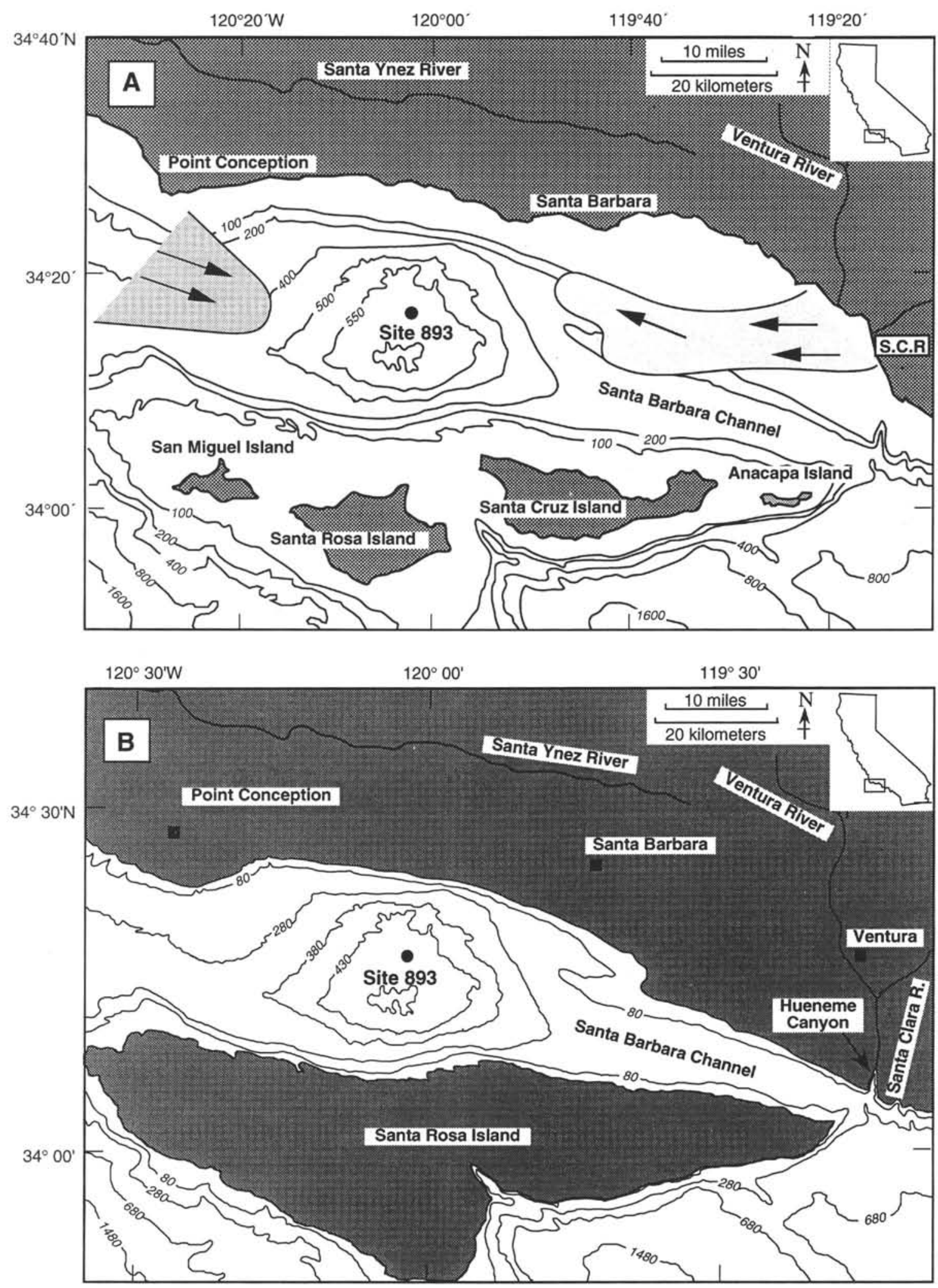

Figure 1. A. Bathymetric map of the Santa Barbara Basin showing the location of Site 893 (modified from Kennett, Baldauf, et al., 1994). Sources of riverderived silt (from the east-Santa Clara and Ventura Rivers) and fan-derived silt (from the west of Point Conception) are also shown (after Thornton, 1984). B. Estimated bathymetry of the Santa Barbara Basin during the Last Glacial Maximum (18 ka) showing the location of Site 893. Note the expansion of land areas seaward and the resulting restriction of the Santa Barbara Channel to the southeast. 
susceptibility and/or digital color signatures. These "events" may provide the basis for future correlations between Site 893 and additional piston cores collected around the Santa Barbara Basin; they can also be used to support continuing research aimed at improving the stratigraphy of laminated intervals at Site 893.

We will begin our detailed study by matching distinctive features in the magnetic susceptibility and digital color data between Holes $893 \mathrm{~A}$ and $893 \mathrm{~B}$. Following this, we will use our identification of the correlative "events" from these two holes to develop a spliced (composite) record for the time interval from the present day to approximately 16 ka (kilo-annum, or 1000 yr ago), just after the Last Glacial Maximum (LGM) in North America. The LGM was a time when the geographic boundaries of the basin were much different than at present due to lowered sea level and the progradation of coastal environments across the shelf margin (Fig. 1B).

\section{METHODS}

\section{Introduction}

The construction of a spliced (composite) record using cores recovered from the two holes at Site 893 was challenging; both because of the widespread disruption resulting from gas expansion in the cores (most core expansion occurred along bedding planes; thus maintaining the paleoceanographic value of the sediment), and because of the lack of routine shipboard physical property and magnetic susceptibility measurements owing to time constraints at the end of Leg 146; these measurements are normally provided by sensors mounted on the multisensor track aboard JOIDES Resolution.

The former difficulty was largely resolved when R. Merrill and F. Rack identified (and manually removed from the sensor data) all of the gas-created voids $>1 \mathrm{~cm}$ along the axis of the core, using visual observations of core photographs and digital color imaging data (see Merrill and Beck, Tables 1 and 2, this volume, and core photographs). The void tables were used to construct a void-corrected depth scale for each of the two holes. These void-corrected depth scales have subsequently been used to provide corrected depths for curated (extracted) samples (R. Merrill, pers. comm.) and have been applied to most (ideally all) of the data sets presented in this volume.

The latter difficulty (i.e., lack of near-continuous core measurements) was resolved through the collection of two complementary data sets on the split cores from each hole - that is, measurements of magnetic susceptibility (Rack et al., this volume) and digital color imaging data (Merrill and Beck, this volume). The digital color and magnetic susceptibility data from the upper $70 \mathrm{mbsf}$ (void-corrected depth) of Holes 893A and 893B (Fig. 2) have enabled us to correlate features (peaks and troughs) between Holes 893A and 893B at centimeter depth-scales.

\section{Development of an Age Model and Splice Table}

The chronology used in this paper for Hole 893A is based on 12 radiocarbon accelerator massspectrometry (AMS) age dates and interpreted oxygen isotope results from planktonic foraminifers (Ingram and Kennett, this volume; Kennett, this volume); the oxygen isotope stages have been correlated to the chronology of Martinson et al. (1987). Additional age constraints were provided by pollen analyses (Huesser, this volume) and by information from various biostratigraphic studies. The age-depth picks used in this study are plotted for the entire recovered interval at Hole 893A and for the upper 36 mbsf, in Figure 3A and 3B, respectively.

The Hole $893 \mathrm{~A}$ age model has been applied to Hole $893 \mathrm{~B}$ by matching correlative features (peaks and troughs) in the magnetic susceptibility records from each of the two holes and thus transfer the Hole $893 \mathrm{~A}$ ages to the equivalent Hole 893B depths. This procedure was accomplished using "Analyseries" software for Macintosh computers (software provided by L. Labeyrie).
In this paper, a systematic methodology was used to identify features in the magnetic susceptibility data set and to correlate these with the higher spatial-resolution digital color data sets. The general procedures were as follows: (1) the individual peaks in the magnetic susceptibility data from either hole were identified and named as coherent "events" (see Table 1); (2) these event assignments were compared with well-defined peaks/troughs in the digital color data sets; (3) the interhole event identifications were then used to select sections of continuous data in either hole, avoiding both core breaks and significantly disturbed intervals, to develop a "splice table" for the construction of a complete (composite) section; and, (4) the composite magnetic susceptibility record was transformed into the age domain to provide an overview of the past $16 \mathrm{ka}$.

\section{Magnetic Susceptibility Data}

Magnetic susceptibility measurements were routinely made on split-core sections from Holes $893 \mathrm{~A}$ and $893 \mathrm{~B}$ at approximately $5-\mathrm{cm}$ intervals using a Bartington $100-\mathrm{mm}$ magnetic susceptibility wholecore sensor set at the low-frequency $(0.47 \mathrm{kHz})$ scale (see Rack et al, this volume). Background measurements at $10 \mathrm{~cm}$ from the ends (top and bottom) of each core section were made and data quality was monitored throughout the collection process. Measurements taken within $5 \mathrm{~cm}$ of any significant core disturbance or void were removed from the data set to avoid edge effects or other sources of erroneous data.

The magnetic susceptibility data are quite sensitive to the presence of gray silty beds, which are thought to correspond to geologically "instantaneous" depositional events interpreted by previous authors as resulting from past floods of the Santa Clara and Ventura rivers (high precipitation/runoff events) or from earthquake activity (mass movements of sediments).

\section{Digital Color Imaging}

Digital color measurements of cores from Holes 893A and 893B were made at intervals between 0.22 and approximately $1 \mathrm{~mm}$ along the core, using RGB (red-green-blue) images captured by the ODP color digital imaging system. These data were edited by inspection to eliminate artifacts due to voids, foam fillers, cracks, razor scrapes, etc., and were then averaged to obtain one set of values at approximately $1-\mathrm{cm}$ spacing (i.e., 12 values were averaged to obtain each value plotted; see Merrill and Beck, this volume).

A high-resolution color image was captured of each $10-\mathrm{cm}$ inter$\mathrm{val}$ of the split core, overlapping the adjoining images at both ends of each interval, so that each image covers a $13.5-\mathrm{cm}$ length of core. Approximately 4200 digital color images were collected during the 2 weeks immediately following the splitting and describing of the Site 893 cores. Core surfaces were gently scraped with a razor blade to remove surface disturbances, and were then imaged. Measurements were made at the center of the core, and were offset to the right of center (upper part of image) where necessary. The precision of the measurements was to the nearest $0.5 \mathrm{~mm}$, but the messiness of the void boundaries usually prevented this level of accuracy.

The ODP color digital imaging system that captured these images incorporates a Sony DXC-750MD camera equipped with three CCDs (charge coupled devices), to capture red, green, and blue images simultaneously, and a Fujinon TV.Z $4 \times 7.5$ lens. Capture was performed by a Truevision AT-Vista $4 \mathrm{M}$ video capture board mounted in an IBM 386/33 clone. The color temperature of the light source (filtered tungsten) was $5020^{\circ} \mathrm{K}$. Measurements of light actually incident upon samples ranged between $4300^{\circ}$ and $4600^{\circ} \mathrm{K}$, which demonstrated that intensity was uniform throughout the sample area. Calibration standards were captured on a regular basis during imaging. Color analyses of the data were conducted and CIE 1931 chromaticity coordinates ( $x, y$, and $Y=$ luminance) were computed (see Merrill and Beck, this volume). The CIE 1931 chromaticity system is 
Figure 2. Summary plots of smoothed digital color (CIE 1931 [x, y, Y] tristimulus values) and magnetic susceptibility data from the upper $70 \mathrm{~m}$ of Holes $893 \mathrm{~A}$ (A) and 893B (B); the data are plotted vs. void-corrected depth in meters below sea level.
A

Average $\times$ (smoothed)

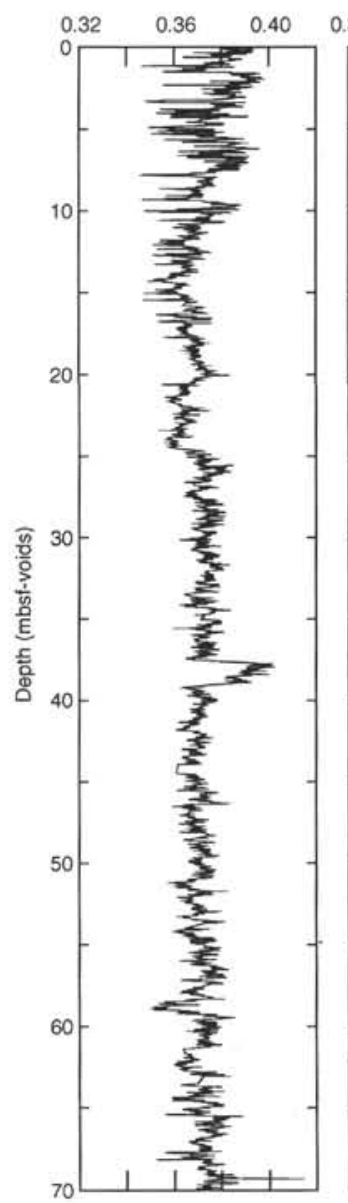

Average y (smoothed)

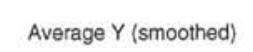

Magnetic susceptibility (SI)

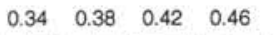

$\begin{array}{llll}2 & 6 & 10 & 140\end{array}$

6

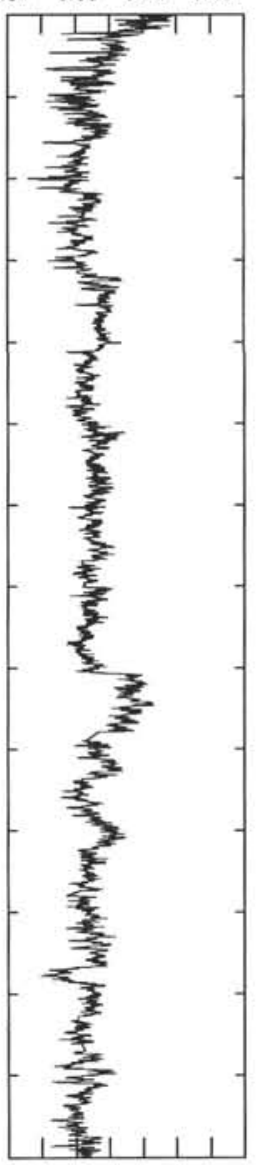

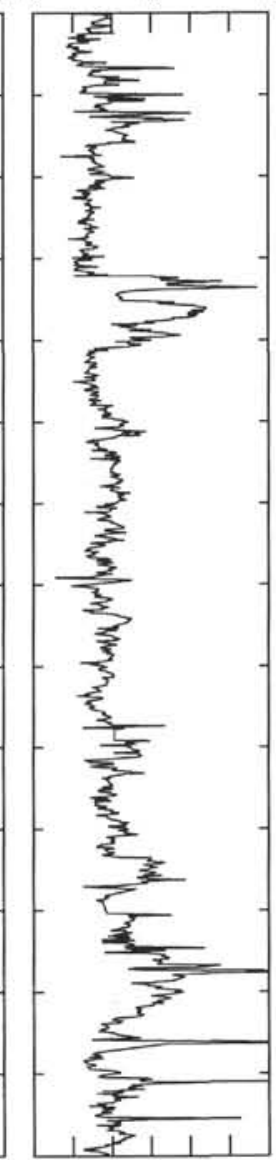

discussed in detail in color science reference texts (see Agoston, 1987; Wyszecki and Styles, 1982). Merrill and Beck (this volume) provide an overview of the CIE chromaticity coordinates $(x, y)$ and their relation to other color systems (e.g., Munsell Color System). The Munsell System is based on a three-coordinate system (hue, value, chroma). Within the CIE chromaticity space, colors are described uniquely and continuously in terms of the three dimensions $(x, y, Y)$. Normal mathematical relationships apply, so the usual statistical manipulations are valid (see Merrill and Beck, this volume).

The CIE 1931 chromaticity space $(x, y, Y)$ is illustrated in Figure 4 (modified from Agoston, 1987); for reference, Munsell hue surfaces are projected into the $(x, y)$ chromaticity plane. Luminance $(Y)$ increases upward in this diagram. The chromaticity luminance coordinate (Y) incorporates all of the "brightness" property of a color. Luminance is the color attribute which, intuitively, is the most similar to gray-scale data (Bond et al., 1992) and color density data (Schaaf and Thurow, this volume).

The color data from Holes 893A and 893B were plotted as twodimensional chromaticity diagrams ( $\mathrm{x}$ vs. $\mathrm{y}$; Fig. 5A, B), and as plots of luminance (Y) vs. $x$ and $y$, respectively (Hole 893A, Fig. 6A, B; Hole 893B, Fig. 7A, B). The vertical and horizontal scales of these plots were held constant so that the reader could easily compare the data from each hole. The digital color data collected from each of the two holes was consistently within the same range of values, with the exception of a "tail" observed in the chromaticity (x vs. y) data from Hole 893B (Fig. 5B). This tail corresponds to the values measured on the surficial sediment $(0-0.75 \mathrm{mbsf})$ from this hole. The large scatter in the surface data may be caused by (1) the higher water contents of the surficial sediment, (2) the color response to geochemical gradients in these sediments, or (3) artifacts in the data arising from the collection procedures or the condition of the core.

In general, decreased values of $\mathrm{x}$ and $\mathrm{y}$ correspond to peaks in luminance $(\mathrm{Y})$, which are also generally associated with gray beds in these cores. The bulk of these peaks can be correlated between holes, although centimeter-scale differences in the records were observed (possibly corresponding to measurement "noise" or natural variability between holes).

\section{RESULTS}

In the following section we will look at the upper 24 mbsf of the magnetic susceptibility and digital color data sets in more detail, since this is the interval where the radiocarbon age model is best defined (see Ingram and Kennett, this volume). We will present individual plots of the magnetic susceptibility and digital color data $(x, y$, and $\mathrm{Y}$ ) for successive $6-\mathrm{m}$ intervals in each hole. Individual distinct features (events) are identified on both the magnetic susceptibility and the luminance $(\mathrm{Y})$ plots for each interval. The numbering system for these events is somewhat arbitrary; higher amplitude events were initially assigned numbers, and then smaller features were assigned number-letter designations (Table 1). Lists of gray beds and massive 


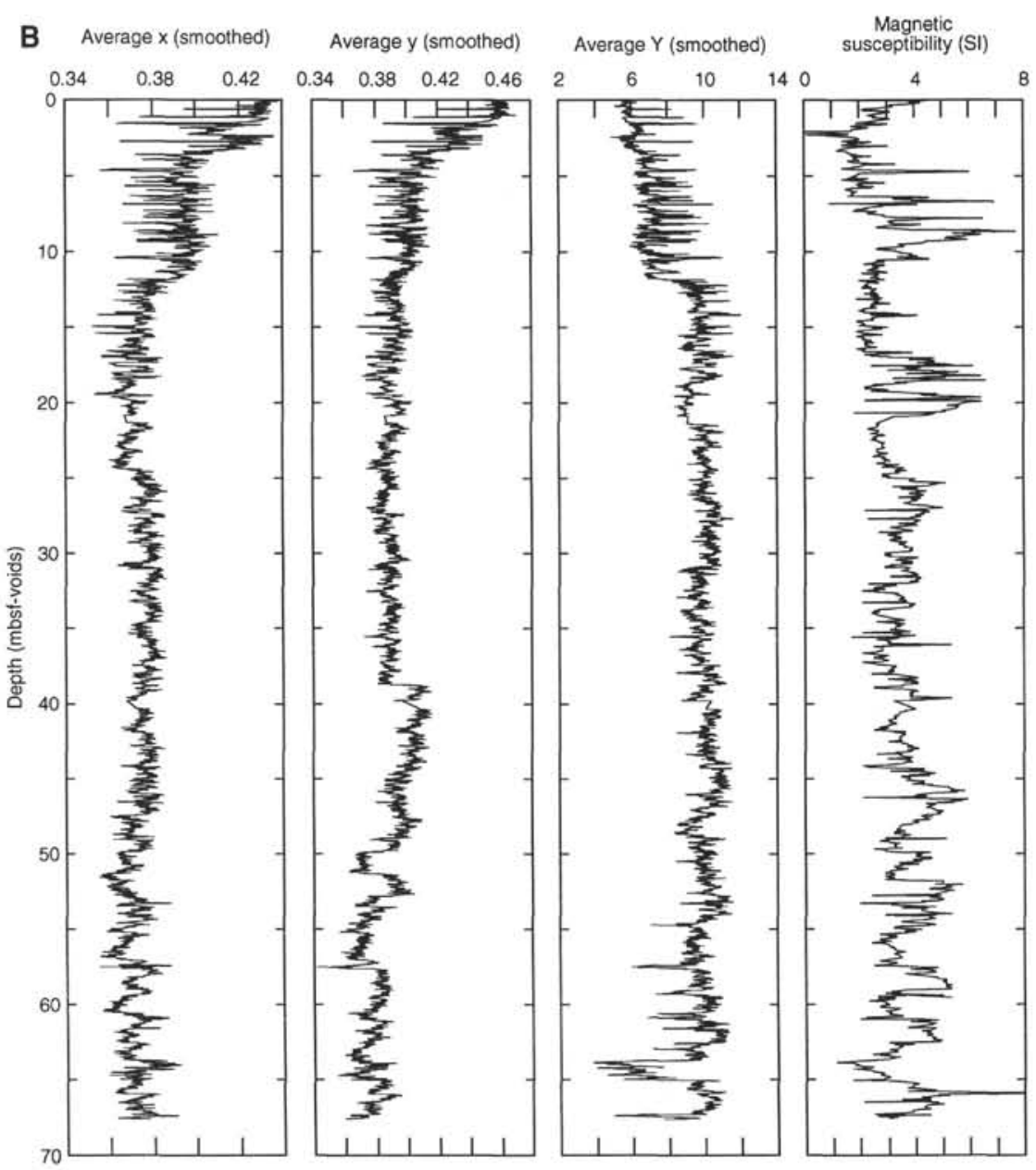

Figure 2 (continued).

intervals in Holes 893A and 893B are given in Tables 2 and 3; these lists were compiled from published core descriptions (Kennett, Baldauf, et al., 1994) and from core photographs.

\section{Magnetic Susceptibility and Digital Color Imaging Data}

In the upper $1.5 \mathrm{~m}$ of Hole $893 \mathrm{~A}$, it is difficult to unambiguously identify data peaks which correlate with Hole 893B. Various attempts at correlation suggest that about 50 to $75 \mathrm{~cm}$ of material recovered in the top of Hole 893B is missing from Hole 893A (compare Fig. $8 \mathrm{~A}$ and $8 \mathrm{~B}$; see Table 1).

Several smaller events (events la through Id) identified between 1.5 and 3.0 mbsf in Hole 893 A are also observed in Hole 893B (2.7 to $4.3 \mathrm{mbsf}$ ); these layers are about the same thickness in each of the two holes, with the exception of event Id (see Tables 2 and 3). Sedimentologic descriptions of the massive intervals in the upper $10 \mathrm{mbsf}$ of each hole differ; silty clay nannofossil ooze dominates in Hole $893 \mathrm{~A}$, while diatom nannofossil silty clay dominates in Hole $893 \mathrm{~B}$ (Kennett, Baldauf, et al, 1994). These differences may be an artifact of the core description process; actual lithologies should be similar.

The first completely unambiguous tiepoint is event $2 a$, which is identified by large peaks in magnetic susceptibility and luminance values and troughs in $x$ and $y$ chromaticity values (see Fig. $8 \mathrm{~A}, \mathrm{~B}$ ); this event is correlated with thick gray beds in each hole $(13 \mathrm{~cm}$ thick in Hole 893A and $14 \mathrm{~cm}$ thick in Hole 893B; see Tables 2 and 3). Starting at about $50 \mathrm{~cm}$ below event $2 \mathrm{a}$, two groups of three susceptibility peaks each are observed in both holes (events $2 b-2 d$ and $3 a-$ 3c, respectively; see Figs. 8A, 8B, and 9B; Table 1). Additional low amplitude features are reflected in the digital color data because of the more closely spaced measurements of these parameters. These two triplets (of peaks or troughs) are best preserved in Hole 893A, where they are located in Sections 146-893A-1H-3 and $1 \mathrm{H}-4$, respectively, and are associated with individual gray layers of variable thicknesses (see Table 2). The event 3 magnetic susceptibility triplet in Hole 893B is positioned across a core-section break between Sections $146-893 \mathrm{~B}-2 \mathrm{H}-3$ and $2 \mathrm{H}-4$, and is therefore somewhat deformed in comparison to the corresponding feature in Hole 893A. The color data provides a better comparison between these intervals (in the lower portion of Fig. 8A and the upper portion of Fig. 9B).

Events 4 and 5 (Fig. 9A, B; Table 1) are identified by broad increases in magnetic susceptibility values. These events are shown to be comprised of a number of gray beds ( $1-10 \mathrm{~cm}$ thick) that are clearly observed in the digital color data and in core photographs (Kennett. Baldauf, et al., 1994); these beds are best developed in Hole 893B (Fig. 9B; Table 3). According to core descriptions, the sediments recovered in Hole 893B throughout the interval containing events 4 and 5 , consist of moderately to distinctly laminated diatom silty clays intercalated with a large number of well-preserved gray beds and olive gray, massive, partly bioturbated intervals (Kennett, Baldauf, et al., 1994). In Hole $893 \mathrm{~A}$, these features are located near the core break between Cores 146-893 A-1 $\mathrm{H}$ and $2 \mathrm{H}$ and are truncated. We suggest that 0.75 to $1.0 \mathrm{~m}$ of sediment is missing from Hole $893 \mathrm{~A}$, as compared to the record in Hole 893B. The interval missing from Hole $893 \mathrm{~A}$ most likely contains events $4 \mathrm{~b}$ and the upper portion of event 5 

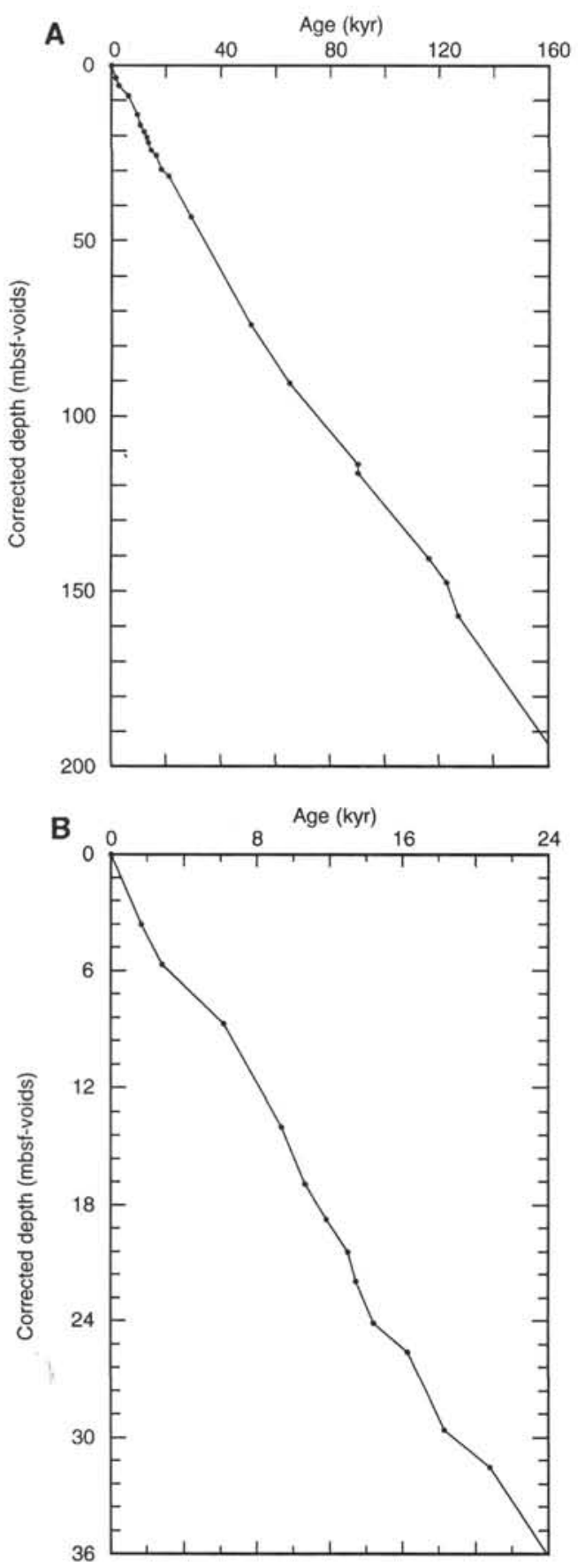

Figure 3. Age vs, void-corrected depth plots for Hole 893A based on the age model of Ingram and Kennett (this volume) for the interval from 0 to 200 mbsf (A). An expanded view of the interval from 0 to $40 \mathrm{mbsf}$ (B) is annotated with AMS radiocarbon dates from Ingram and Kennett (this volume).

(i.e., 5a, 5b, and 5c). A comparison of the observed fluctuations in the digital color data from each hole across this interval seems to support this interpretation (Figs. 9A, B).

About I $\mathrm{m}$ below the base of Event 5, there is a gradual increase in susceptibility to a peak identified as event $6 \mathrm{a}$ in each hole (Fig. 9A, $\mathrm{B}$; Table 1); this event is associated with clearly defined changes in digital color (peak in luminance, troughs in $\mathrm{x}$ and $\mathrm{y}$ ). This event is correlated with a relatively thick gray layer in each hole $(9 \mathrm{~cm}$ thick in Hole 893A; $13 \mathrm{~cm}$ thick in Hole 893B). Another gray layer, located about $80 \mathrm{~cm}$ to $1 \mathrm{~m}$ below event $6 \mathrm{a}$ in each hole, is identified as event
Table 1. Depth tie-points between Holes 893A and 893B based on (interpreted) magnetic susceptibility events.

\begin{tabular}{|c|c|c|c|}
\hline Event & $\begin{array}{c}893 \mathrm{~A} \\
\mathrm{~V} \text { depth } \\
\text { (mbsf) }\end{array}$ & $\begin{array}{c}893 \mathrm{~B} \\
\text { V depth } \\
\text { (mbsf) }\end{array}$ & $\begin{array}{c}\text { Offset } \\
\text { (m) }\end{array}$ \\
\hline (a) & 0.05 & 0.80 & 0.75 \\
\hline (b) & 0.30 & 1.25 & 0.95 \\
\hline (c) & 0.45 & 1.58 & 1.13 \\
\hline (d) & 0.75 & 1.83 & 1.08 \\
\hline (e) & 1.20 & 2.21 & 1.01 \\
\hline $\mathrm{IH} / 2 \mathrm{H}$ & - & 2.22 & - \\
\hline la & 1.55 & 2.77 & 1.22 \\
\hline Ib & 1.75 & 3.02 & 1.27 \\
\hline Ic & 2.35 & 3.65 & 1.32 \\
\hline Id & $3.00=$ & 4.19 & 1.19 \\
\hline $2 a$ & 3.35 & 4.69 & 1.34 \\
\hline $2 b$ & 3.85 & 5.19 & 1.34 \\
\hline $2 \mathrm{c}$ & 4.10 & 5.42 & 1.32 \\
\hline $2 \mathrm{~d}$ & 4.35 & 5.67 & 1.32 \\
\hline $3 \mathrm{a}$ & 4.95 & 6.42 & 1.47 \\
\hline $3 b$ & 5.20 & 6.67 & 1.47 \\
\hline $3 c$ & 5.35 & 6.88 & 1.53 \\
\hline $4 a$ & 6.08 & 7.77 & 1.69 \\
\hline $4 b$ & - & 8.17 & $\overline{2}$ \\
\hline $5 a$ & $6.40^{*}$ & 8.63 & 2.23 \\
\hline $1 \mathrm{H} / 2 \mathrm{H}$ & 6.50 & - & - \\
\hline $5 b$ & - & 8.83 & - \\
\hline $5 c$ & - & 9.18 & - \\
\hline $5 d$ & 6.68 & 9.33 & 2.65 \\
\hline $5 e$ & 6.93 & 9.58 & 2.65 \\
\hline $6 a$ & 7.83 & 10.42 & 2.59 \\
\hline $6 \mathrm{~b}$ & 8.65 & 11.37 & 2.72 \\
\hline $6 c$ & 9.36 & $11.75^{*}$ & 2.39 \\
\hline $2 \mathrm{H} / 3 \mathrm{H}$ & - & 11.80 & - \\
\hline $7 \mathrm{a}$ & 9.86 & - & - \\
\hline $7 b$ & 10.06 & - & - \\
\hline $7 \mathrm{c}$ & 10.68 & - & - \\
\hline $8 \mathrm{a}$ & 11.87 & - & - \\
\hline $8 b$ & 12.12 & - & - \\
\hline $8 b^{\prime}$ & 12.37 & 12.26 & -0.11 \\
\hline $8 c$ & 12.60 & 12.41 & -0.19 \\
\hline $8 d$ & 12.78 & 12.69 & -0.09 \\
\hline $8 \mathrm{e}$ & 13.08 & $13.04^{*}$ & -0.04 \\
\hline $8 \mathrm{f}$ & 13.32 & 13.38 & 0.06 \\
\hline $8 g$ & 14.22 & 14.23 & 0.01 \\
\hline $9 \mathrm{a}$ & 14.87 & 14.97 & 0.10 \\
\hline $9 b$ & 15.02 & 15.07 & 0.05 \\
\hline $9 \mathrm{c}$ & 15.47 & 15.47 & 0.00 \\
\hline $2 \mathrm{H} / 3 \mathrm{H}$ & 16.00 & $\overline{-}$ & - \\
\hline $10 \mathrm{a}$ & - & 16.64 & - \\
\hline $10 \mathrm{~b}(\mathrm{t})$ & - & 16.99 & - \\
\hline $10 \mathrm{~b}(\mathrm{~b})$ & - & 17.54 & - \\
\hline $11 \mathrm{a}$ & 16.15 & 17.96 & 1.81 \\
\hline IIb & 16.40 & 18.21 & 1.81 \\
\hline $11 \mathrm{c}$ & 16.77 & 18.49 & 1.72 \\
\hline $12 \mathrm{a}$ & 17.62 & 19.38 & 1.76 \\
\hline $12 \mathrm{~b}(\mathrm{t})$ & 17.82 & 19.58 & 1.76 \\
\hline $12 b(b)$ & 18.52 & $20.55^{\text {zit }}$ & 2.03 \\
\hline $3 \mathrm{H} / 4 \mathrm{H}$ & - & 21.30 & - \\
\hline $13 \mathrm{a}$ & 19.62 & - & - \\
\hline $13 b$ & 19.93 & - & - \\
\hline $13 \mathrm{c}$ & 20.18 & - & - \\
\hline $13 \mathrm{~d}$ & 20.56 & - & - \\
\hline $3 \mathrm{H} / 4 \mathrm{H}$ & 25.50 & - & - \\
\hline
\end{tabular}

Notes: $\mathrm{V}$ depth $=$ void-corrected depth. *Poorly defined event located at section break, in core catcher, or near a void. Offset was calculated by subtracting the V depth of each event in Hole 893A from the depth of the corresponding event in Hole 893B.

$6 \mathrm{~b}$ (see Tables 2 and 3). An underlying, poorly defined feature in Hole 893A (identified as event $6 \mathrm{c}$ ) is associated with a 4-cm-thick gray layer; this feature is clearly observed in the digital color data as a series of three peaks in luminance (Fig. 9A) but is thought to be missing from Hole 893B owing to the core break between Cores 146$893 \mathrm{~B}-2 \mathrm{H}$ and $3 \mathrm{H}$.

An additional series of susceptibility and luminance peaks identified in Hole 893A (event 7) have no easily identifiable correlative features in Hole 893B. We believe that this may indicate a gap in sediment recovery between Cores 146-893B-2 $\mathrm{H}$ and $3 \mathrm{H}$ of 1.5 to $2.0 \mathrm{~m}$ of sediment relative to Hole $893 \mathrm{~A}$; this is based on the thickness of events $6 \mathrm{c}$ and 7 in Hole 893A (Fig. 9A; Table 3). Event 7b is associated with a $13-\mathrm{cm}$-thick gray layer, which underlies a $4-\mathrm{cm}$-thick 


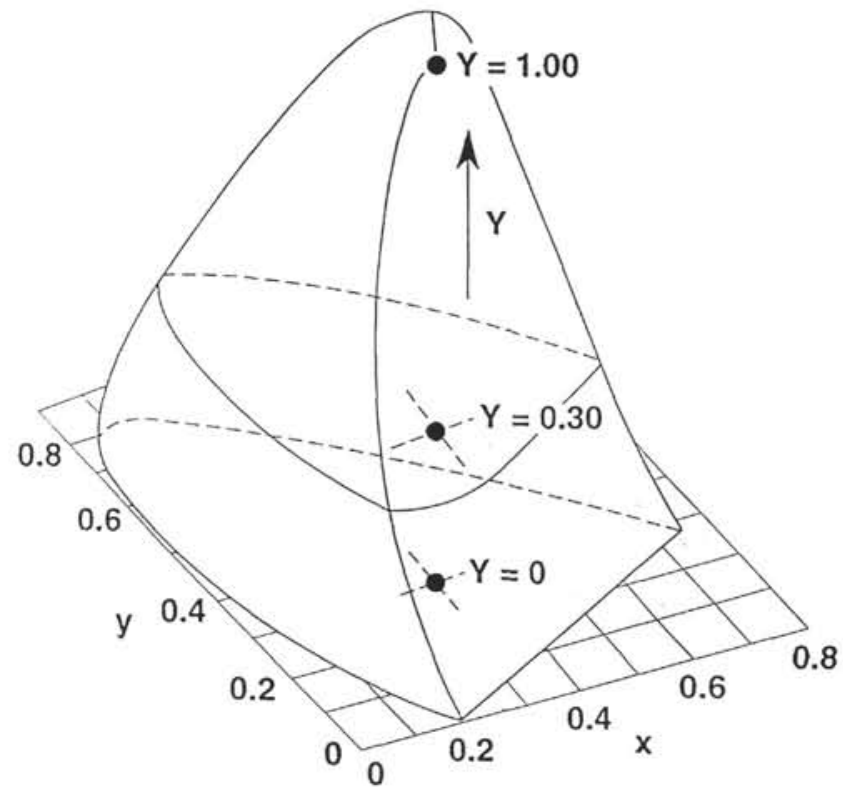

Figure 4. This figure presents the CIE 1931 (x, y, Y) color space for light scattered by non-self-luminous objects illuminated by a light source (modified from Agoston, 1987).

gray layer (event 7a). We believe that these features would be readily apparent in the cores from Hole 893B, if this interval were recovered.

The next two series of events, identified in Table 1 as events 8 and 9 , provide correlations between these two holes that are highly speculative because of their low amplitude in the magnetic susceptibility record. The color data provides fairly good correlations between the two holes within this interval but there are still some uncertainties in the identification of the individual peaks (troughs) in each hole. If our correlations are correct, then the offset between the two holes for this interval is effectively equal to zero (i.e., no offset; see Table I).

The most distinctive and prominent features in the magnetic susceptibility records from the upper $24 \mathrm{mbsf}$ of each hole at Site 893 , are the series of high-amplitude peaks identified in Table I as events 10 through 13 (see Figs. 10A, B and 11A, B). The sediment descriptions suggest that these features correspond to massive and structureless intervals of diatom nannofossil silty clay and diatom nannofossil clayey silt, with sporadic thin to medium interbeds of gray silty clay and nannofossil silty clay (Kennett, Baldauf, et al., 1994).

The first set of susceptibility peaks (event 10 ) is only observed in Hole 893B (Fig. 10A, B); this suggests that about $1.5 \mathrm{~m}$ of sediment is missing from Hole $893 \mathrm{~A}$ across the core break between Cores 146$893 \mathrm{~A}-2 \mathrm{H}$ and $3 \mathrm{H}$. Following a decrease in susceptibility values below event $10 \mathrm{~b}$, there is a series of three susceptibility peaks (event 11); these peaks can be observed in both holes (see Figs. 10A and IIA, B), although the peaks exhibit a slightly different character in Hole 893A (smoothly varying) than in Hole 893B (more jagged). A distinctive decrease in magnetic susceptibility values (trough), extending for about $0.75 \mathrm{~m}$, separates events 11 and 12 in both holes; this trough seems to be slightly wider in Hole 893B than in Hole $893 \mathrm{~A}$.

Event 12 is observed as a broad susceptibility peak in Hole 893A, but is disrupted in Hole $893 \mathrm{~B}$ by section breaks between Sections 146-893B-3H-6, 3H-7, and 3H-CC, respectively, which result in decreased susceptibility values at about 19.5 and 20.5 mbsf (Fig. 1IB). Event 13 seems to be missing from Hole 893B between Cores 146 $893 \mathrm{~B}-3 \mathrm{H}$ and $4 \mathrm{H}$; this event is well preserved in Hole $893 \mathrm{~A}$ (Fig. 11A). The bulk of the data in the deeper sections of each hole provide poorly constrained correlations between holes because of the low am-
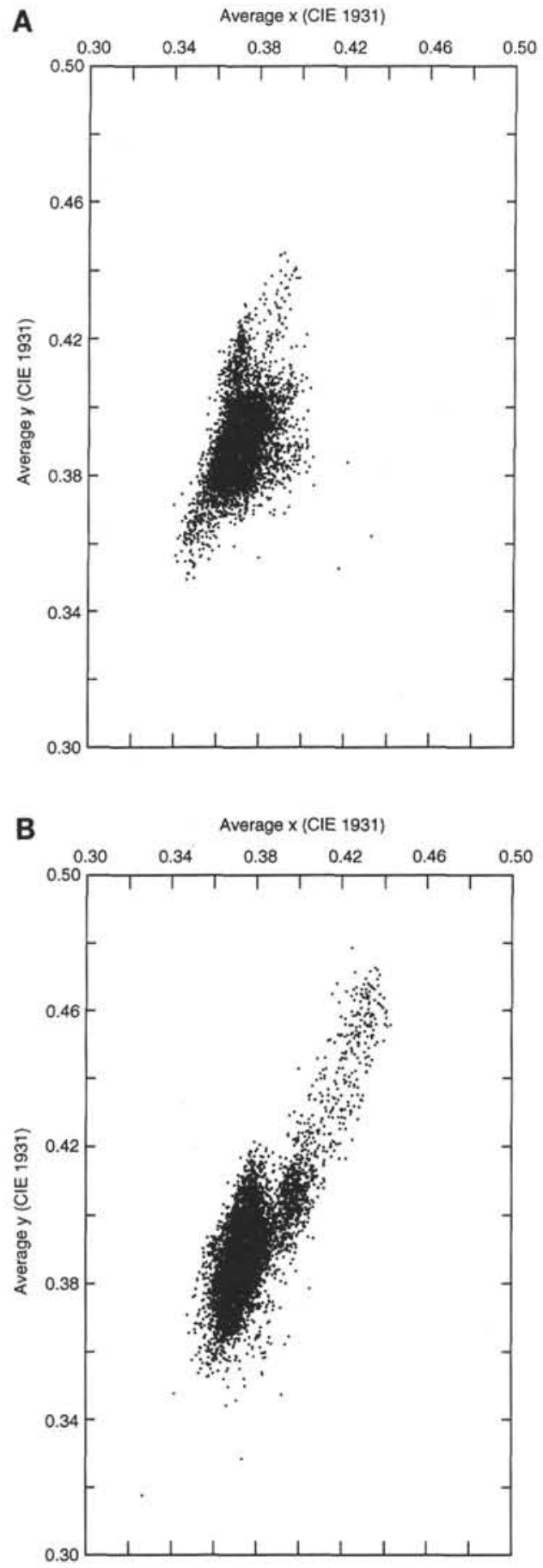

Figure 5. Scatterplot chromaticity diagrams showing $(x, y)$ digital color data collected from Hole 893A (A) and Hole 893B (B).

plitude of both the magnetic susceptibility and the color data. We have not attempted to extend our analysis further at this time.

\section{Development of a 16-k.y. Spliced (Composite) Record}

One of the primary objectives of this study was to attempt to develop a composite stratigraphic section for Site 893 , which would fill in the missing intervals between holes owing to coring gaps and core disturbance. A composite record would also provide an accurate and 
A

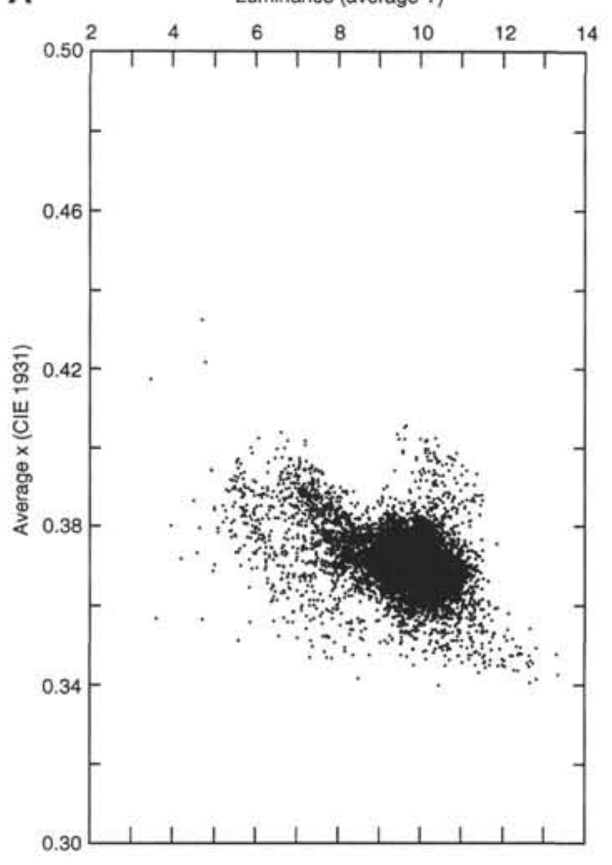

B

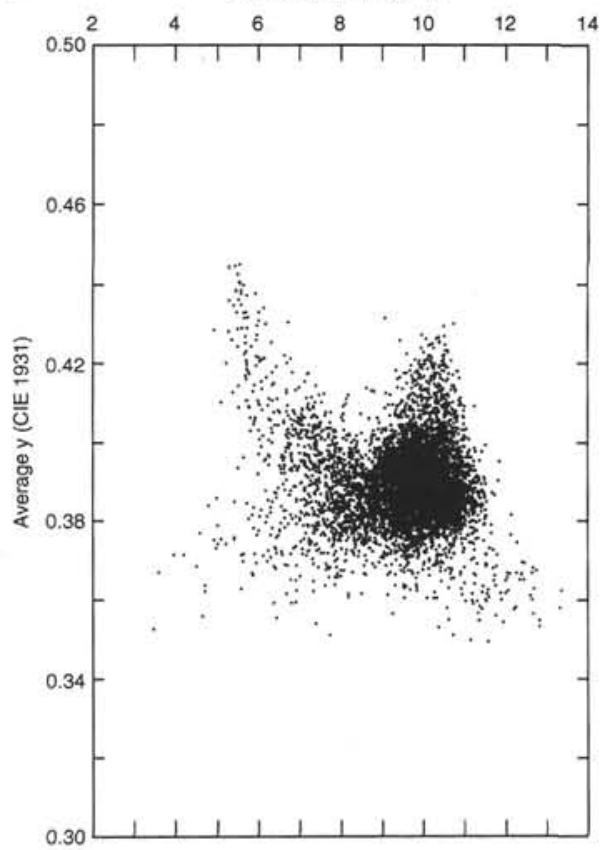

Figure 6. Scatterplots of digital color $(\mathrm{x}, \mathrm{y})$ parameters vs. luminance $(\mathrm{Y})$ values measured on cores collected from 0 to $70 \mathrm{mbsf}$ in Hole 893A. A. $x$ vs. $\mathrm{Y}$ values. B. $y$ vs. Y values. Note the similarities between the data distribution in these plots and those shown in Figure 7.

complete record of property fluctuations at this site for use in the interpretation of paleoenvironmental changes. We have utilized the magnetic susceptibility data from the upper $24 \mathrm{mbsf}$ of each hole to build a composite stratigraphic section for the interval from the present day to about $16 \mathrm{ka}$.

The magnetic susceptibility and digital color data from Hole $893 \mathrm{~A}$ and Hole $893 \mathrm{~B}$ are shown in Figure 12 vs. age. As was shown
A

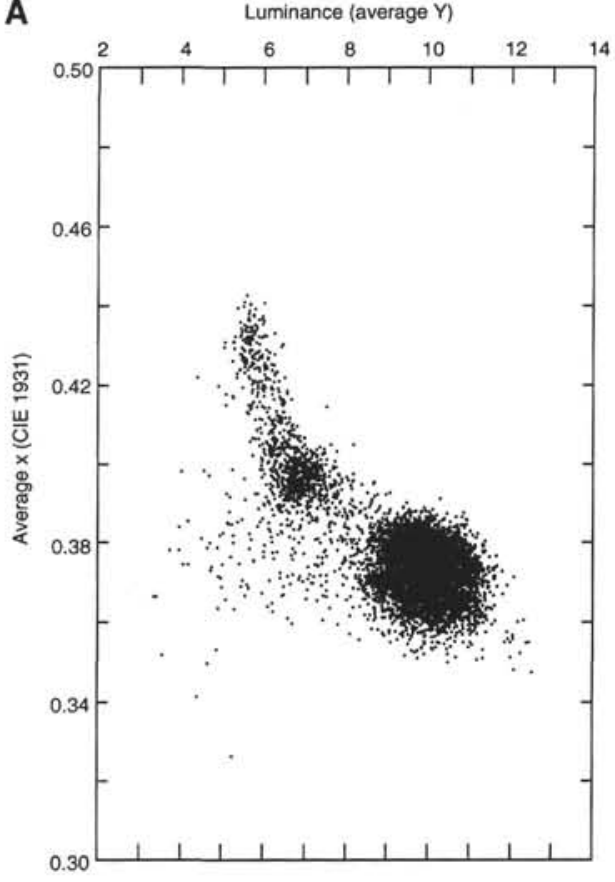

B

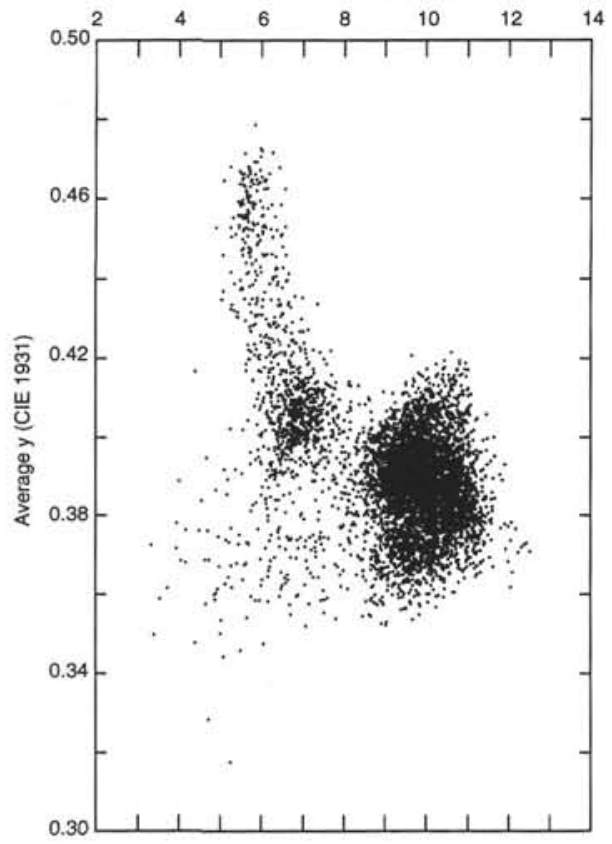

Figure 7. Scatterplots of digital color (x, y) parameters vs. luminance (Y) values measured on cores collected from 0 to $70 \mathrm{mbsf}$ in Hole 893B. A. $\mathrm{x}$ vs. $\mathrm{Y}$ values. B. $\mathrm{y}$ vs. $\mathrm{Y}$ values. Note the expanded tail of $\mathrm{x}$ and $\mathrm{y}$ values toward the upper left (i.e., higher $x$ or $y$ and lower luminance values) in these plots, compared to those shown in Figure 6.

in the preceding set of detailed figures (Figs. 8 through 11), similar fluctuations in each type of data are observed in both holes. A composite section constructed from the two magnetic susceptibility profiles incorporates our reconstruction of the "ideal" susceptibility record for the shallow sediments $(0-30 \mathrm{mbsf})$ recovered from Site 893. 
Table 2. Gray beds, massive intervals, and sand layers, Hole 893A.

\begin{tabular}{|c|c|c|c|c|c|c|}
\hline \multirow{2}{*}{$\begin{array}{l}\text { Core, section, } \\
\text { interval }(\mathrm{cm})\end{array}$} & \multicolumn{3}{|c|}{$\mathrm{V}$ depth (mbsf) } & \multirow{2}{*}{$\begin{array}{l}\text { Layer thickness } \\
\text { (cm) }\end{array}$} & \multirow[b]{2}{*}{ Type } & \multirow[b]{2}{*}{ Event } \\
\hline & Top & Bottom & Middle & & & \\
\hline $146-893 \mathrm{~A}-$ & & & & & & \\
\hline $1 \mathrm{H}-1,0-13$ & 0.00 & 0.13 & 0.07 & 13.00 & SCNO & (a) \\
\hline $1 \mathrm{H}-1,41-53$ & 0.41 & 0.53 & 0.47 & 12.00 & SCNO & (c) \\
\hline $1 \mathrm{H}-1.64-66$ & 0.64 & 0.66 & 0.65 & 2.00 & GB & \\
\hline $\mathrm{IH}-\mathrm{I}, 70-91$ & 0.70 & 0.91 & 0.81 & 21.00 & SCNO & (d) \\
\hline $1 \mathrm{H}-1,116-121$ & 1.16 & 1.21 & 1.19 & 5.00 & GB & (e) \\
\hline $1 \mathrm{H}-1.145-150$ & 1.45 & 1.50 & 1.48 & 5.00 & GB & la \\
\hline $1 \mathrm{H}-2,19-26$ & 1.69 & 1.76 & 1.73 & 7.00 & SCNO & Ib \\
\hline IH-2, $61-62$ & 2.11 & 2.12 & 2.12 & 1.00 & GB & \\
\hline IH- $2,68-80$ & 2.18 & 2.30 & 2.24 & 12.00 & SCNO & \\
\hline $\mathrm{IH}-2,83-88$ & 2.33 & 2.38 & 2.36 & 5.00 & $\mathrm{~GB}$ & Ic \\
\hline $1 \mathrm{H}-2,109-110$ & 2.59 & 2.60 & 2.59 & 1.00 & $\mathrm{~GB}$ & \\
\hline $\mathrm{IH}-2,128-128$ & 2.78 & 2.78 & 2.78 & 0.75 & GB & \\
\hline $\mathrm{IH}-2.138-150$ & 2.88 & 3.00 & 2.94 & 12.00 & SCNO & Id \\
\hline IH-3, 24-37 & 3.24 & 3.37 & 3.31 & 13.00 & GB & $2 \mathrm{a}$ \\
\hline IH $-3,46-65$ & 3.46 & 3.65 & 3.56 & 19.00 & SCNO & \\
\hline IH $-3,82-86$ & 3.82 & 3.86 & 3.84 & 4.00 & GB & $2 \mathrm{~b}$ \\
\hline IH-3,96-97 & 3.96 & 3.99 & 3.97 & 3.00 & $\mathrm{~GB}$ & \\
\hline $1 \mathrm{H}-3,101-102$ & 4.01 & 4.02 & 4.02 & 1.00 & GB & \\
\hline $1 \mathrm{H}-3,105-110$ & 4.05 & 4.10 & 4.08 & 5.00 & GB & $2 \mathrm{c}$ \\
\hline$|\mathrm{H}-3,120-12|$ & 4.20 & 4.21 & 4.20 & 1.00 & GB & \\
\hline IH $-3,123-124$ & 4.23 & 4.24 & 4.24 & 1.00 & GB & \\
\hline $1 \mathrm{H}-3,132-135$ & 4.32 & 4.35 & 4.34 & 3.00 & $\mathrm{~GB}$ & $2 d$ \\
\hline $1 \mathrm{H}-4,7-8$ & 4.52 & 4.53 & 4.52 & 0.75 & GB & \\
\hline IH $-4,38-49$ & 4.88 & 4.99 & 4.94 & 11.00 & GB & $3 \mathrm{a}$ \\
\hline $\mathrm{HH}-4.57-58$ & 5.07 & 5.08 & 5.08 & 1.00 & GB & \\
\hline IH $-4,60-61$ & 5.10 & 5.11 & 5.11 & 1.00 & GB & \\
\hline IH $-4,64-72$ & 5.14 & 5.22 & 5.18 & 8.00 & GB & $3 b$ \\
\hline $\mathrm{IH}-4,80-86$ & 5.30 & 5.36 & 5.33 & 6.00 & GB & $3 c$ \\
\hline IH-4, 93-114 & 5.43 & 5.64 & 5.54 & 21.00 & SCNO & \\
\hline $1 \mathrm{H}-4,119-121$ & 5.69 & 5.71 & 5.70 & 2.00 & GB & \\
\hline IH $-4,138-140$ & 5.86 & 5.88 & 5.87 & 2.00 & GB & \\
\hline IH $-4,143-144$ & 5.91 & 5.92 & 5.92 & 0.75 & GB & \\
\hline IH-5, 2-3 & 6.00 & 6.01 & 6.01 & 1.00 & SCNO & \\
\hline IH-5, 4-9 & 6.02 & 6.07 & 6.05 & 5.00 & SCNO & $4 a$ \\
\hline $1 \mathrm{H}-5,14-15$ & 6.12 & 6.13 & 6.13 & 1.00 & SCNO & \\
\hline IH-CC, 9-11 & 6.34 & 6.36 & 6.35 & 2.00 & SCNO & \\
\hline IH-CC, $23-24$ & 6.48 & 6.49 & 6.49 & 1.00 & SCNO & \\
\hline $2 \mathrm{H}-1,4-1 \mathrm{I}$ & 6.54 & 6.61 & 6.58 & 7.00 & GB & \\
\hline $2 \mathrm{H}-1,22-26$ & 6.70 & 6.74 & 6.72 & 4.00 & GB & $5 d$ \\
\hline $2 \mathrm{H}-1,42-46$ & 6.90 & 6.94 & 6.92 & 4.00 & GB & $5 e$ \\
\hline $2 \mathrm{H}-\mathrm{I}, 102-102$ & 7.50 & 7.51 & 7.50 & 0.75 & GB & \\
\hline $2 \mathrm{H}-1,114-115$ & 7.62 & 7.63 & 7.63 & 1.00 & $G B$ & \\
\hline $2 \mathrm{H}-1,124-135$ & 7.72 & 7.83 & 7.78 & 11.00 & $\mathrm{~GB}$ & $6 \mathrm{a}$ \\
\hline $2 \mathrm{H}-1,146-148$ & 7.93 & 7.95 & 7.94 & 2.00 & GB & \\
\hline $2 \mathrm{H}-2,62-65$ & 8.62 & 8.65 & 8.64 & 3.00 & GB & $6 b$ \\
\hline $2 \mathrm{H}-2,111-112$ & 9.07 & 9.08 & 9.08 & 1.00 & GB & \\
\hline $2 \mathrm{H}-2,126-128$ & 9.22 & 9.24 & 9.23 & 2.00 & GB & \\
\hline $2 \mathrm{H}-2,133-134$ & 9.29 & 9.31 & 9.30 & 0.75 & GB & \\
\hline $2 \mathrm{H}-2,136-140$ & 9.32 & 9.36 & 9.34 & 4.00 & $\mathrm{~GB}$ & $6 c$ \\
\hline $2 \mathrm{H}-3,5-6$ & 9.49 & 9.50 & 9.50 & 1.00 & GB & \\
\hline $2 \mathrm{H}-3,41-42$ & 9.82 & 9.83 & 9.83 & 1.00 & GB & \\
\hline $2 \mathrm{H}-3,45-49$ & 9.86 & 9.90 & 9.88 & 4.00 & GB & $7 \mathrm{a}$ \\
\hline $2 \mathrm{H}-3,55-68$ & 9.96 & 10.09 & 10.02 & 13.00 & GB & $7 \mathrm{~b}$ \\
\hline $2 \mathrm{H}-3.120-128$ & 10.61 & 10.66 & 10.63 & 5.00 & GB & $7 \mathrm{c}$ \\
\hline $2 \mathrm{H}-4,0-2$ & 10.86 & 10.88 & 10.87 & 2.00 & GB & \\
\hline $2 \mathrm{H}-4,15-16$ & 11.01 & 11.02 & 11.02 & 1.00 & GB & \\
\hline $2 \mathrm{H}-4,33-34$ & 11,16 & 11.17 & 11.17 & 1.00 & GB & \\
\hline $2 \mathrm{H}-4,114-116$ & 11.86 & 11.88 & 11.87 & 2.00 & GB & $8 \mathrm{a}$ \\
\hline $2 \mathrm{H}-4,126-128$ & 11.98 & 12.00 & 11.99 & 2.00 & GB & \\
\hline $2 \mathrm{H}-4,14 \mathrm{I}-144$ & 12.13 & 12.16 & 12.15 & 3.00 & GB & $8 b ?$ \\
\hline $2 \mathrm{H}-5,45-48$ & 12.60 & 12.63 & 12.61 & 3.00 & GB & $8 \mathrm{c}$ \\
\hline $2 \mathrm{H}-5,63-65$ & 12.72 & 12.74 & 12.73 & 2.00 & GB & \\
\hline $2 \mathrm{H}-5,68-69$ & 12.77 & 12.78 & 12.77 & 0.75 & GB & $8 \mathrm{~d}$ \\
\hline $2 \mathrm{H}-5,70-7 \mathrm{I}$ & 12.79 & 12.80 & 12.79 & 0.75 & GB & \\
\hline $2 \mathrm{H}-5,73-74$ & 12.82 & 12.83 & 12.83 & 1.00 & GB & \\
\hline $2 \mathrm{H}-5,77-103$ & 12.85 & 13.11 & 12.98 & 26.00 & DNSC & $8 \mathrm{e}$ ? \\
\hline $2 \mathrm{H}-5,97-98$ & 13.05 & 13.06 & 13.06 & 1.00 & $\mathrm{~s}$ & \\
\hline $2 \mathrm{H}-5,129-131$ & 13.31 & 13.33 & 13.32 & 2.00 & GB & $8 f ?$ \\
\hline $2 \mathrm{H}-6,96-97$ & 14.38 & 14.39 & 14.39 & 1.00 & GB & \\
\hline $2 \mathrm{H}-6,143-150$ & 14.85 & 14.92 & 14.89 & 7.00 & $\mathrm{~GB}$ & $9 \mathrm{a}$ \\
\hline $2 \mathrm{H}-7,10-15$ & 15.02 & 15.07 & 15.05 & 5.00 & GB & $9 \mathrm{~b}$ \\
\hline $2 \mathrm{H}-7.51-57$ & 15.43 & 15.49 & 15.46 & 6.00 & GB & $9 c$ \\
\hline $3 \mathrm{H}-1,7-9$ & 16.07 & 16.09 & 16.08 & 2.00 & SC & Ila \\
\hline $3 \mathrm{H}-1,28-37$ & 16.28 & 16.37 & 16.33 & 9.00 & SC & IIb \\
\hline $3 \mathrm{H}-1,70-85$ & 16.67 & 16.82 & 16.75 & 15.00 & SC & $11 \mathrm{c}$ \\
\hline $3 \mathrm{H}-\mathrm{I}, 95-96$ & 16.92 & 16.93 & 16.93 & 1.00 & SC & \\
\hline $3 \mathrm{H}-2.25-26$ & 17.72 & 17.73 & 17.72 & 1.00 & GB & \\
\hline $3 \mathrm{H}-4,15-19$ & 20.56 & 20.60 & 20.58 & 4.00 & GB & $13 d$ \\
\hline
\end{tabular}

Notes: $\mathrm{V}$ depth $=$ depth in void-corrected meters below seafloor (the $\mathrm{V}$ depth is provided for the top, bottom, and midpoint of each layer). Type $=$ lithology given in core description from Kennett, Baldauf, et al. (1994) or interpreted by this study (DNSC $=$ diatom nannofossil silty clay; $\mathrm{GB}=$ gray bed; $\mathrm{S}=$ sand; $\mathrm{SC}=$ silty clay; $\mathrm{SCNO}=$ silty clay nannofossil ooze). Event numbers correspond to individual magnetic susceptibility peaks identified by Rack and Merrill (this volume), which are used to correlate between Holes $893 \mathrm{~A}$ and $893 B$. 
Table 3. Gray beds, massive intervals, and sand layers, Hole 893B.

\begin{tabular}{|c|c|c|c|c|c|c|}
\hline \multirow{2}{*}{$\begin{array}{l}\text { Core, section, } \\
\text { interval }(\mathrm{cm})\end{array}$} & \multicolumn{3}{|c|}{$V$ depth (mbsf) } & Layer thickness & & \\
\hline & Top & Bottom & Middle & $(\mathrm{cm})$ & Type & Event \\
\hline 146-893B- & & & & & & \\
\hline $1 \mathrm{H}-1,41-54$ & 0.41 & 0.54 & 0.48 & 13.00 & DNSC & \\
\hline IH-1, 64-65 & 0.64 & 0.65 & 0.64 & 1.00 & GB & \\
\hline $1 \mathrm{H}-1,75-92$ & 0.70 & 0.87 & 0.79 & 17.00 & DNSC & (a) \\
\hline $1 \mathrm{H}-1,123-124$ & 1.18 & 1.18 & 1.18 & 0.30 & GB & \\
\hline $1 \mathrm{H}-1,124-129$ & 1.19 & 1.24 & 1.21 & 4.50 & GB & (b) \\
\hline $\mathrm{IH}-2,10-19$ & 1.53 & 1.62 & 1.58 & 9.00 & GB & (c) \\
\hline $\mathrm{IH}-2,35-43$ & 1.78 & 1.86 & 1.82 & 8.00 & DNSC & (d) \\
\hline $1 \mathrm{H}-\mathrm{CC}, 14-20$ & 2.20 & 2.26 & 2.23 & 6.00 & DNSC & (e?) \\
\hline $2 \mathrm{H}-1,51-59$ & 2.73 & 2.81 & 2.77 & 8.00 & GB & la \\
\hline $2 \mathrm{H}-1,79-86$ & 3.01 & 3.08 & 3.05 & 7.00 & DSC & $\mathrm{Ib}$ \\
\hline $2 \mathrm{H}-1,123-124$ & 3.45 & 3.46 & 3.46 & 1.00 & GB & \\
\hline $2 \mathrm{H}-1,131-141$ & 3.53 & 3.63 & 3.58 & 10.00 & DSC & \\
\hline $2 \mathrm{H}-1.145-150$ & 3.67 & 3.72 & 3.70 & 5.00 & GB & Ic \\
\hline $2 \mathrm{H}-2,19-20$ & 3.93 & 3.94 & 3.93 & 1.00 & GB & \\
\hline $2 \mathrm{H}-2,37-38$ & 4.11 & 4.12 & 4.12 & 1.00 & GB & \\
\hline $2 \mathrm{H}-2,48-51$ & 4.22 & 4.25 & 4.24 & 3.00 & DSC & Id? \\
\hline $2 \mathrm{H}-2.86-100$ & 4.60 & 4.74 & 4.67 & 14.00 & GB & $2 \mathrm{a}$ \\
\hline $2 \mathrm{H}-2,107-125$ & 4.81 & 4.99 & 4.90 & 18.00 & DSC & \\
\hline $2 \mathrm{H}-2,144-148$ & 5.18 & 5.22 & 5.20 & 4.00 & GB & $2 b$ \\
\hline $2 \mathrm{H}-3,4-6$ & 5.31 & 5.33 & 5.32 & 2.00 & GB & \\
\hline $2 \mathrm{H}-3,9-11$ & 5.36 & 5.38 & 5.37 & 2.00 & GB & \\
\hline $2 \mathrm{H}-3,13-16$ & 5.40 & 5.43 & 5.41 & 3.00 & GB & $2 \mathrm{c}$ \\
\hline $2 \mathrm{H}-3,27-28$ & 5.54 & 5.55 & 5.55 & 1.00 & GB & \\
\hline $2 \mathrm{H}-3,29-30$ & 5.56 & 5.57 & 5.57 & 1.00 & GB & \\
\hline $2 \mathrm{H}-3,39-43$ & 5.66 & 5.70 & 5.68 & 4.00 & GB & $2 d$ \\
\hline $2 \mathrm{H}-3,7 \mathrm{I}-73$ & 5.98 & 6.00 & 5.99 & 2.00 & GB & \\
\hline $2 \mathrm{H}-3,107-119$ & 6.34 & 6.46 & 6.40 & 12.00 & GB & $3 a$ \\
\hline $2 \mathrm{H}-3,136-14 \mathrm{I}$ & 6.63 & 6.68 & 6.66 & 5.00 & GB & $3 b$ \\
\hline $2 \mathrm{H}-4,4-10$ & 6.82 & 6.88 & 6.85 & 6.00 & GB & $3 c$ \\
\hline $2 \mathrm{H}-4,11-50$ & 6.89 & 7.27 & 7.08 & 39.00 & DSC & \\
\hline $2 \mathrm{H}-4,53-55$ & 7.30 & 7.32 & 7.31 & 2.00 & GB & \\
\hline $2 \mathrm{H}-4,56-66$ & 7.33 & 7.43 & 7.38 & 10.00 & DSC & \\
\hline $2 \mathrm{H}-4,75-77$ & 7.52 & 7.55 & 7.53 & 3.00 & GB & \\
\hline $2 \mathrm{H}-4,80-8 \mathrm{I}$ & 7.57 & 7.58 & 7.58 & 1.00 & GB & \\
\hline $2 \mathrm{H}-4,94-96$ & 7.71 & 7.73 & 7.72 & 2.00 & GB & \\
\hline $2 \mathrm{H}-4,96-102$ & 7.73 & 7.79 & 7.76 & 6.00 & GB & $4 a$ \\
\hline $2 \mathrm{H}-4,139-142$ & 8.16 & 8.19 & 8.17 & 3.00 & GB & $4 b$ \\
\hline $2 \mathrm{H}-4,148-149$ & 8.25 & 8.26 & 8.26 & 1.00 & GB & \\
\hline $2 \mathrm{H}-5,26-36$ & 8.59 & 8.69 & 8.64 & 10.00 & GB & $5 \mathrm{a}$ \\
\hline $2 \mathrm{H}-5,45-5 \mathrm{I}$ & 8.78 & 8.84 & 8.81 & 6.00 & GB & $5 b$ \\
\hline $2 \mathrm{H}-5,71-73$ & 9.04 & 9.06 & 9.05 & 2.00 & GB & \\
\hline $2 \mathrm{H}-5,84-93$ & 9.17 & 9.26 & 9.22 & 9.00 & GB & $5 c$ \\
\hline $2 \mathrm{H}-5,103-107$ & 9.36 & 9.40 & 9.38 & 4.00 & GB & $5 \mathrm{~d}$ \\
\hline $2 \mathrm{H}-5,11 \mathrm{I}-149$ & 9.44 & 9.82 & 9.63 & 38.00 & SC & $5 e ?$ \\
\hline $2 \mathrm{H}-6,44-45$ & 10.26 & 10.27 & 10.27 & 1.00 & GB & \\
\hline $2 \mathrm{H}-6,54-67$ & 10.36 & 10.49 & 10.42 & 13.00 & GB & $6 \mathrm{a}$ \\
\hline $2 \mathrm{H}-6,78-80$ & 10.60 & 10.62 & 10.61 & 2.00 & GB & \\
\hline $2 \mathrm{H}-7,3-7$ & 11.35 & 11.39 & 11.37 & 4.00 & GB & $6 \mathrm{~b}$ \\
\hline $2 \mathrm{H}-7,52-54$ & 11.84 & 11.90 & 11.87 & 6.00 & GB & $6 c$ \\
\hline $2 \mathrm{H}-\mathrm{CC}, 10-11$ & 11.97 & 11.98 & 11.98 & 1.00 & GB & \\
\hline $2 \mathrm{H}-\mathrm{CC}, 15-16$ & 12.02 & 12.03 & 12.03 & 1.00 & GB & \\
\hline $3 \mathrm{H}-1,2 \mathrm{I}-22$ & 11.97 & 11.98 & 11.98 & 1.00 & GB & \\
\hline $3 \mathrm{H}-1,32-33$ & 12.08 & 12.09 & 12.09 & 1.00 & GB & \\
\hline $3 \mathrm{H}-1,47-49$ & 12.23 & 12.25 & 12.24 & 2.00 & GB & $8 b ?$ \\
\hline $3 \mathrm{H}-1,58-71$ & 12.34 & 12.47 & 12.41 & 13.00 & DNSC & $8 \mathrm{c} ?$ \\
\hline $3 \mathrm{H}-1,97-100$ & 12.66 & 12.69 & 12.67 & 3.00 & GB & $8 \mathrm{~d}$ \\
\hline $3 \mathrm{H}-1,11 \mathrm{I}-114$ & 12.80 & 12.83 & 12.82 & 3.00 & GB & \\
\hline $3 \mathrm{H}-1.116-117$ & 12.85 & 12.86 & 12.86 & 1.00 & GB & \\
\hline $3 \mathrm{H}-1,122-149$ & 12.91 & 13.13 & 13.02 & 21.00 & DNSC & $8 \mathrm{e}$ ? \\
\hline $3 \mathrm{H}-2,0-60$ & 13.13 & 13.73 & 13.43 & 60.00 & DNSC & $8 \mathrm{f} ?$ \\
\hline $3 \mathrm{H}-2,64-75$ & 13.77 & 13.88 & 13.83 & 11.00 & DNSC & \\
\hline $3 \mathrm{H}-2,90-97$ & 14.03 & 14.10 & 14.06 & 7.00 & GB & \\
\hline $3 \mathrm{H}-2,105-111$ & 14.18 & 14.24 & 14.21 & 6.00 & GB & $8 \mathrm{~g} ?$ \\
\hline $3 \mathrm{H}-3,30-35$ & 14.92 & 14.97 & 14.94 & 5.00 & GB & $9 \mathrm{a}$ \\
\hline $3 \mathrm{H}-3,43-49$ & 15.05 & 15.11 & 15.08 & 6.00 & GB & $9 \mathrm{~b}$ \\
\hline $3 \mathrm{H}-3,80-84$ & 15.42 & 15.46 & 15.44 & 4.00 & GB & $9 \mathrm{c}$ \\
\hline $3 \mathrm{H}-3,125-129$ & 15.83 & 15.87 & 15.85 & 4.00 & DNSC & \\
\hline $3 \mathrm{H}-3,140-143$ & 15.98 & 16.01 & 16.00 & 3.00 & DNSC & \\
\hline $3 \mathrm{H}-4,12-13$ & 16.21 & 16.22 & 16.22 & 1.00 & GB & \\
\hline $3 \mathrm{H}-4,15-27$ & 16.24 & 16.36 & 16.30 & 12.00 & DNSC & \\
\hline $3 \mathrm{H}-4,49-59$ & 16.58 & 16.68 & 15.63 & 10.00 & DNSC & $10 \mathrm{a}$ \\
\hline $3 \mathrm{H}-4,69-71$ & 16.78 & 16.80 & 16.79 & 2.00 & GB & \\
\hline $3 \mathrm{H}-4,82-92$ & 16.91 & 16.96 & 16.94 & 5.00 & DNSC** & \\
\hline $3 \mathrm{H}-4,95-107$ & 16.99 & 17.09 & 17.04 & 10.00 & DNSC* & $10 b(t)$ \\
\hline $3 \mathrm{H}-4,114-117$ & 17.16 & 17.19 & 17.18 & 3.00 & GB & \\
\hline $3 \mathrm{H}-4,139-150$ & 17.41 & 17.49 & 17.45 & 8.00 & DNSC** & \\
\hline $3 \mathrm{H}-5,0-10$ & 17.49 & 17.59 & 17.54 & 10.00 & DNSC* & $10 \mathrm{~b}(\mathrm{~b})$ \\
\hline $3 \mathrm{H}-5,68-109$ & 18.05 & 18.30 & 18.18 & 25.00 & DNSC* & $11 \mathrm{~b}$ \\
\hline $3 \mathrm{H}-5,135-149$ & 18.44 & 18.54 & 18.49 & 10.00 & DNSC* & $11 \mathrm{c}$ \\
\hline $3 \mathrm{H}-6,11-12$ & 18.65 & 18.66 & 18.65 & 1.00 & GB & \\
\hline $3 \mathrm{H}-6,107-135$ & 19.45 & 19.73 & 19.59 & 28.00 & DNSC* & $12 b(t)$ \\
\hline $3 \mathrm{H}-7,0-30$ & 19.81 & 20.10 & 19.96 & 30.00 & DNSC $*$ & $12 b(b)$ \\
\hline $3 \mathrm{H}-7,30-8 \mathrm{I}$ & 21.10 & 20.61 & 21.36 & 51.00 & DNSC & \\
\hline $3 \mathrm{H}-\mathrm{CC}, 0-34$ & 20.61 & 20.95 & 20.78 & 34.00 & DNSC & \\
\hline
\end{tabular}

Notes: $\mathrm{V}$ depth = void-corrected depth ( $\mathrm{V}$ depths are provided for the top, bottom, and midpoint of each layer). Type = lithology given in core description from Kennett, Baldauf, et al. (1994) or interpreted by this study (DNSC = diatom nannofossil silty clay; GB = gray bed; $\mathrm{S}=$ sand; * = bioturbated). Event numbers correspond to individual magnetic susceptibility peaks identified by Rack and Merrill (this volume), which are used to correlate between Holes $893 \mathrm{~A}$ and $893 \mathrm{~B}$. 
The methods used to construct this composite section have been outlined in the methods section of this paper. We selected continuous sections of data from each hole so that core breaks and disturbed intervals of core were avoided. We then spliced these sections of data together and developed a revised depth scale based on $\mathrm{m}$ composite depth ( $\mathrm{mcd}$ ) by summing the lengths of the sections of data that were used in the splice (see Table 4). Finally, the spliced data intervals were transformed into the time domain to plot the Site 893 composite vs. age (Fig. 13).

\section{DISCUSSION}

This paper has focused on the potential of using multisensor data sets from adjacent drill holes to construct a composite stratigraphic section (i.e., one that is more complete than either of the individual data sets collected from cores at a given site). We have applied these techniques to cores recovered at Site 893 in the Santa Barbara Basin, where the preservation of laminated intervals and multiple-event beds (e.g., gray layers) provides a potentially invaluable source of nearly continuous, proxy paleoclimatic and paleoceanographic information; these records provide an anticipated seasonal to decadal age resolution, depending on the measurement interval selected for data collection and the sensors used (i.e., digital color vs. magnetic susceptibility data).

\section{Characteristics of Gray Beds and Massive Intervals}

Gray beds of terrigenous silty clay are frequently interbedded with laminated intervals of Holocene sediment at Site 893, but they are less often preserved in the bioturbated or massive zones. These gray silty beds were the subject of several previous studies (Fleischer, 1972; Thornton, 1984; among others) where they are described as "suspended-load deposits derived mainly from the Santa Clara River during large floods" (Fleischer, 1972). Alternatively, some of the gray silty beds were described as fine-grained turbidites, possibly originating from a "line source" (laterally distributed region of slope failure) on the upper shelf region to the west of Santa Barbara (Thornton, 1984); essentially to the north or northeast of Site 893 .

Thin gray beds ( $<2 \mathrm{~cm}$ thick) are much more clearly defined in the digital color data than in the magnetic susceptibility data plots (see Figs. 8-11; Tables 2,3), both because of the increased along-core spatial resolution of the digital color measurements and the apparently highly sensitive response of digital color parameters ( $\mathrm{x}, \mathrm{y}$, and $\mathrm{Y})$ to changes in physical properties (i.e., water content) and sediment composition. Both types of measurements detect the thicker gray beds ( $>3 \mathrm{~cm}$ thick) and may also provide additional information about subtle differences in grain size and/or sorting of the sediment within these layers, through more detailed analyses of changes in the amplitude and shape of individual data peaks (troughs).

We assume that most of the gray beds discussed in this study are related to geologically instantaneous events (i.e., increased sediment transport by rivers during peak flood years; and mass movements of sediment initiated by earthquake accelerations) which produce discrete sedimentary layers. Additional research will determine the uncompacted sediment thickness, structure, and provenance of each of the identified gray layers at Site 893 . These studies will enable us to (1) recalculate sedimentation rates at Site 893 (after removing the influence of gray layers) and (2) establish an improved chronology for the timing and frequency of these events during the Holocene.

\section{Magnetite Dissolution Related to Sediment Diagenesis}

Recent studies in anoxic and/or suboxic borderland basins have focused on changes in specific geochemical relationships and on the cycling of elements (e.g., organic carbon, nitrogen sulphur, and oxy- gen; Berelson, et al., 1987; Jahnke, 1990; Schimmelmann and Kastner, 1993), since these factors influence the preservation of sedimentologic events and paleoclimatic signals (Lange et al., 1987, 1990; Schimmelmann et al., 1990, 1992). The preservation of laminated sediment intervals is thought to be primarily controlled by the low oxygen content of bottom waters and by the presence of dense bacterial mats on the seafloor, which restrict the amount of bioturbation caused by organisms (Emery and Hülsemann, 1962; Fleischer, 1972; Soutar and Crill, 1977; Reimers et al., 1990). These conditions may also contribute to the dissolution of magnetic minerals in sediments.

In anoxic or suboxic basins, and in shelf regions where a distinct oxygen-minimum zone develops, geochemical processes are fundamentally important to the preservation and subsequent interpretation of sediment magnetic records (Karlin and Levi, 1983, 1985). In these settings, it is necessary to determine the effects of magnetite dissolution and iron-sulfur diagenesis on the observed paleomagnetic record (Karlin, 1990a, 1990b; Leslie et al., 1990a, 1990b) so that it is possible to identify which of the observed changes are related to paleoceanographic fluctuations and which are caused by diagenetic overprints (Lund et al., 1992).

Studies of the rock magnetic properties of sediments from several California borderland basins (Brandsma et al., 1989; Leslie et al., 1990a, 1990b; Lund et al., 1992) have shown that distinct differences in sedimentation rate, composition, and magnetic properties can be detected between borderland basins. These studies have also demonstrated that (1) the natural remanent magnetism of borderland sediments is primarily carried by detrital magnetite, although local contributions from other sources are sometimes important (e.g., detrital and authigenic hematite, altered glauconite, and biogenic magnetite); (2) the proportion of magnetic material decreases outward from the coastline because of dilution from biogenic sources; (3) the average magnetic grain size decreases away from the coastline; and (4) magnetic dissolution caused by early sediment diagenesis is an ubiquitous process, especially in the deeper basins (see summary provided by Lund et al., 1992).

Understanding the role of diagenetic processes in the Santa Barbara Basin is critical for evaluating the significance of proxy records; however, at present, we are not able to assess the magnitude of these effects on the magnetic susceptibility or digital color records. Future research will focus on the measurement of additional rock magnetic properties (i.e., the anhysteretic [ARM], saturation [SIRM], and isothermal [IRM] remanent magnetization) on selected samples from Site 893 and will determine how variations in magnetic mineral grain size and composition reflect physical changes in the sedimentary environment and/or diagenetic processes. The integration of data from additional geochemical studies, such as are contained in this volume, will also contribute to these objectives.

\section{Sea-level Variations and Sediment Transport Processes}

Numerous studies have evaluated the quality and chronology of various estimates of sea level for the late Quaternary (Bard et al., 1989, 1990; Edwards, et al., 1993; Fairbanks, 1989; Gallup et al., 1994; Peltier, 1994; Tushingham and Peltier, 1991; among others). The predicted or measured changes in relative mean sea level are intimately related to the rate and timing of changes in global ice volume and to the interaction of ice sheets with the ocean and solid earth through changes in paleotopography (Peltier, 1994; Tushingham and Peltier, 1991).

During the Last Glacial Maximum (LGM), sea level was approximately $\sim 121 \pm 5 \mathrm{~m}$ below present level (Fairbanks, 1989), as reflected by significant changes in the geometry of the Santa Barbara Basin (compare Fig. 1A and 1B). The effects of rising sea level may best be observed during the Flandrian Transgression (e.g., from about 18 to $10 \mathrm{ka}$, with a short period of regression at about $12 \mathrm{ka}$; Nardin et al., 

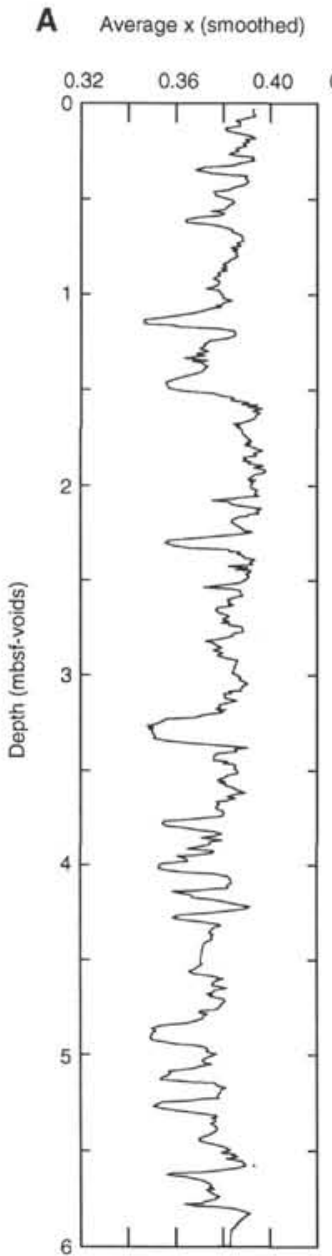
$\begin{array}{lllll}0.34 & 0.38 & 0.42 & 0.46 & 2\end{array}$

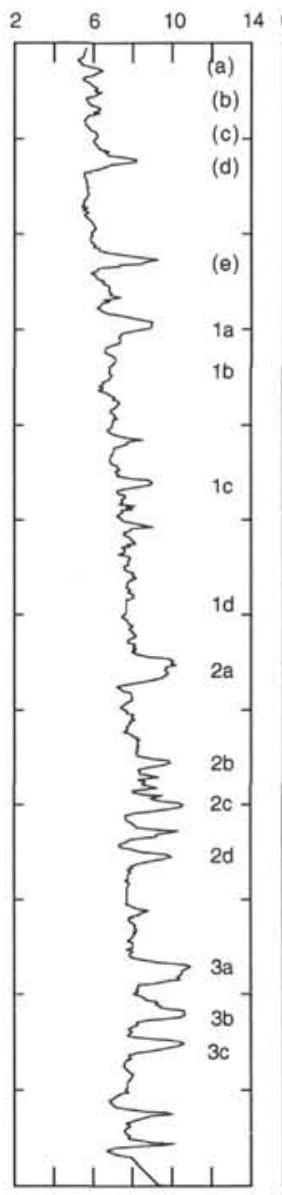
40 6 12
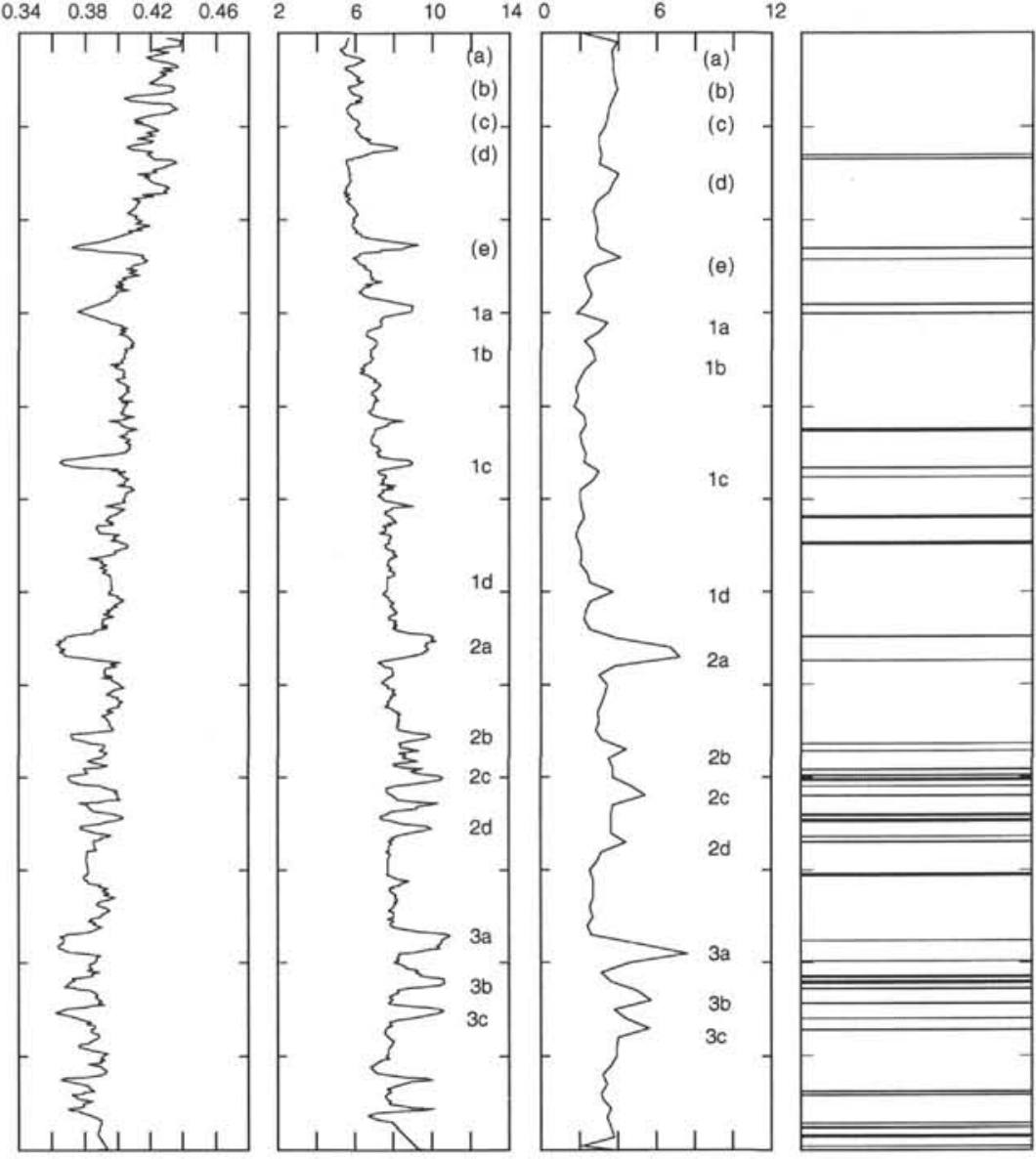

Figure 8. Summary plots of smoothed digital color (CIE 1931 [x, y, Y] tristimulus values) and magnetic susceptibility data for the interval from 0 to 6 mbsf (void-corrected depth). A. Hole 893A. B. Hole 893B. Events listed in Table 1 are annotated on the magnetic susceptibility and luminance plots; the positions of individual "gray layers" in Hole 893A are also shown.

1981), which included the retreat of coastal areas across the shelf, a reduction in stream gradients, and a probable decrease in the delivery of river-borne sediments to the central basin (Schwalbach and Gorsline, 1985). The inferred fluctuations in the rate of sea-level rise/ fall may have significantly altered the sediment budget of the Santa Barbara basin for extended periods.

During the Flandrian Transgression, most of the sediment entering the basin may have been trapped in the drowned river valleys and on the upper shelf with only limited fine sediment reaching the "starved" slopes and basins (Schwalbach and Gorsline, 1985). Most significant for the record at Site 893, is the interpretation that the series of large magnetic susceptibility peaks between 13 and $10 \mathrm{ka}$ (see Fig. 13) may reflect the increased delivery of terrigenous sediments to the deep basin during the short period of sea-level regression within the general Flandrian Transgression.

The establishment of contemporary oceanographic circulation patterns and the lower rates of sea-level rise over the past 8 ka may have allowed the shelf-to-basin system to reach near-equilibrium regarding sediment input vs. output, so that large inputs of sediment during floods (storms) are directly transferred to the basin floor (Schwalbach and Gorsline, 1985) and are ultimately preserved as gray beds (Drake et al., 1972; Fleischer, 1972; Gorsline et al., 1984; Thornton, 1981, 1984, 1986).

\section{Paleoclimatic and Paleoceanographic Interpretations}

In addition to the primary control of sea level on the sediment budget of the Santa Barbara Basin, the most intriguing explanation for the series of large susceptibility peaks located at $\sim 16$ to $20 \mathrm{mbsf}$ $(10-13 \mathrm{ka})$ is the suggestion that they are the results of a period of increased precipitation (and continental runoff) in southern California and the entire western region of North America. Observations which suggest increased mean precipitation within the interval from $\sim 10$ to $13 \mathrm{ka}$ are frequently found in the palynological literature concerned with the western region of North America, from California to British Columbia (Heusser, 1978, 1988; Heusser et al., 1980, 1985; Mathewes and Heusser, 1981; Rypins et al., 1989; Thompson et al., 1993).

Heusser (this volume) observe a large increase in alder pollen concentrations within this specific interval of Hole 893A. Alder populations are generally concentrated along stream beds in the Santa Barbara-Ventura region, thus providing a probable link between increased stream flow and the increased flux of alder pollen to the basin (L. Huesser, pers. comm.).

An atmospheric mechanism for providing increased precipitation to central and southern California was suggested by the modeling results of the Cooperative Holocene Mapping Project (COHMAP 


\section{B}

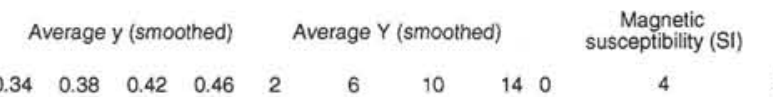

Gray beds

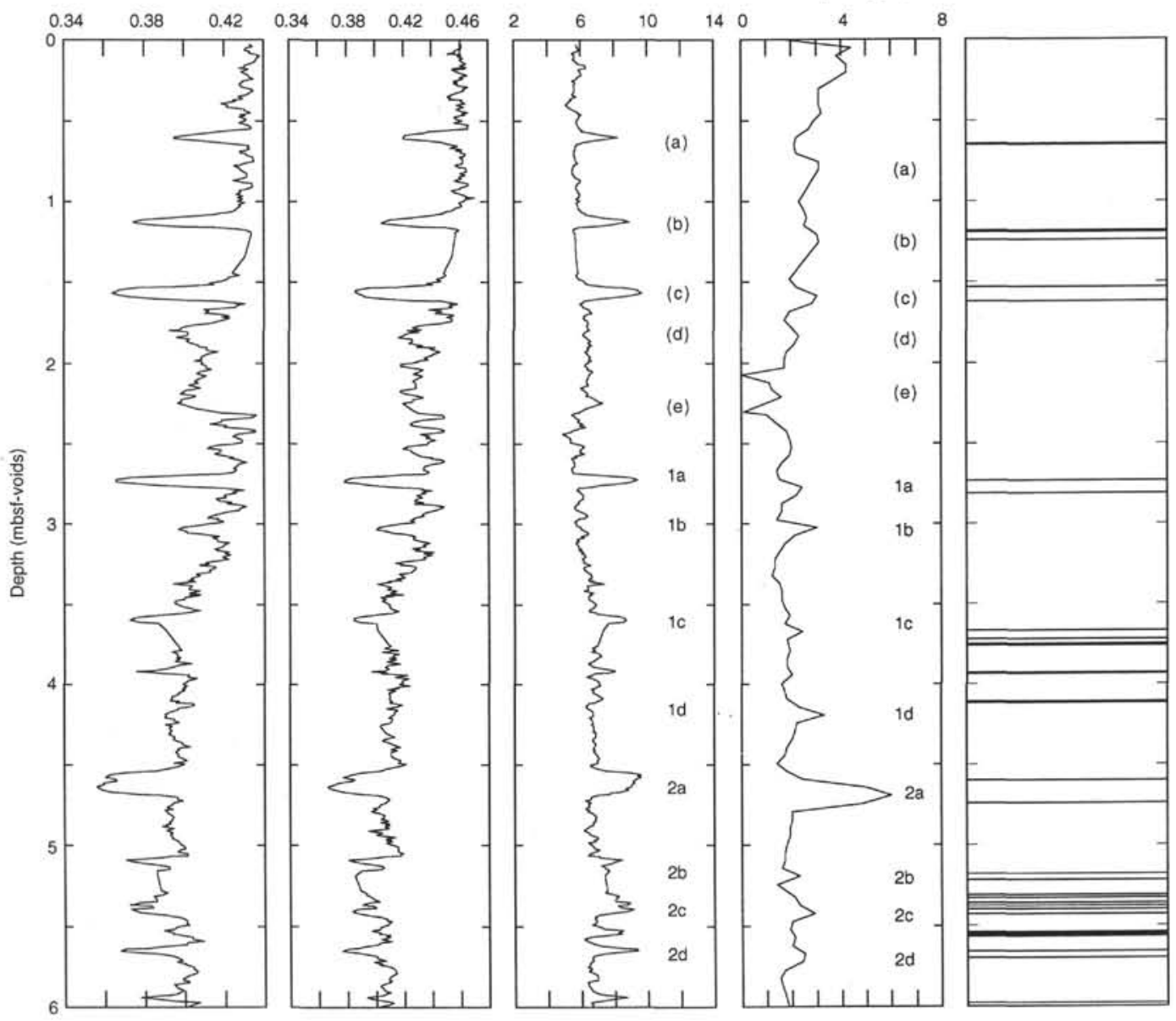

Figure 8 (continued).

members, 1988; Kutzbach and Webb, 1993; Thompson et al., 1993). These model simulations show an increase in storm tracks across the southwestern United States between 18 and $9 \mathrm{ka}$, caused by a southerly displaced, westerly jet stream over North America. The boundary conditions used in these simulations may need to be revised to provide more realistic model results (Peltier, 1994), and to resolve time-steps shorter than about $3000 \mathrm{yr}$ (Kutzbach and Ruddiman, 1993), but they provide support for our assertions.

From 15 to $6 \mathrm{ka}$, the enhanced thermal contrast between land and sea may have produced strong summer monsoons, which also served to increase effective moisture across this region (Kutzbach and Webb, 1993; Thompson et al., 1993). Thompson et al. (1993) indicate that following the wet period around $12 \mathrm{ka}$, conditions along the southern California coast may have led to a somewhat drier climate until after $6 \mathrm{ka}$, followed by moister conditions over the past $3 \mathrm{ka}$. These patterns may have been caused by changes in summer precipitation and insolation and a strengthened Pacific subtropical highpressure cell, although considerable climatic variation may be masked by the model resolution (Kutzbach and Webb, 1993; Thompson et al. 1993).

Finally, changes in the oxygen isotope records from the Greenland Ice Core Project (GRIP) ice core (Dansgaard et al., 1993; Greenland Ice-core Project Members, 1993; Fig. 13) and the Greenland Ice Sheet Project II (GISP2) ice core may reflect changes in atmospheric circulation and precipitation patterns during the Younger Dryas and at other times (Alley et al., 1993; Charles et al., 1994; Mayewski et al., 1994). It is intriguing to speculate that the magnetic susceptibility and digital color data from Site 893 may also record this paleo-atmospheric connection between the western region of North America and Greenland.

\section{CONCLUSIONS}

In this paper, we have correlated between Holes 893A and 893B at the centimeter scale using our identification of 53 discrete "events" in the upper 24 mbsf of each hole. These events correspond to identified peaks (troughs) in magnetic susceptibility and digital color data. These interhole correlations were used to identify continuous sections of (magnetic susceptibility) data, which were spliced together to construct a composite section vs. age for the past 16 ka (Fig. 13); this composite is thought to be more complete than the individual records in either of the two holes.

Our interpretation of magnetic susceptibility and digital color data from the upper portion of Site 893 suggests that sea-level fluctuations have exerted a primary control on long-term sediment depositional and transport processes, since the Last Glacial Maximum. Higher frequency variations in these proxy records are caused by fluctuations in the relative proportions of terrigenous and biogenous sedimentary inputs and by discrete depositional events (floods and mass movements of sediment); diagenetic (reactions) processes may be important within some intervals, but this will require further study. 
We make the following observations (conclusions) based on our comparisons of the data from both holes at Site 893:

I. Approximately $0.75 \mathrm{~m}$ of sediment appears to be missing from the top of Hole 893A (immediately below the sediment surface), based on a comparison with Hole 893B.

2. Approximately 0.75 to $1.0 \mathrm{~m}$ of sediment is missing from Hole $893 \mathrm{~A}$ across the core break between Cores 146-893A-1H and $2 \mathrm{H}$

3. Approximately 1.5 to $2.0 \mathrm{~m}$ of sediment is missing from Hole $893 \mathrm{~B}$ across the core break between Cores 146-893B-2H and $3 \mathrm{H}$.

4. From $\sim 12$ to 16 mbsf in each hole, the offset between Holes $893 \mathrm{~A}$ and $893 \mathrm{~B}$ is reduced to effectively zero (no offset).

5. Approximately $1.5 \mathrm{~m}$ of sediment may be missing from Hole 893B across the core break between Cores 146-893B-3H and $4 \mathrm{H}$, based on the interpretation that Event 13 is missing from this hole (Table 1; Fig. 11A, B).

6. Below $\sim 30$ mbsf, correlations between Holes 893A and 893B are difficult to make because of the poorly developed and lowamplitude features of the data from each hole.

7. The 16-ka magnetic susceptibility spliced (composite) record (Fig. 13) shows two intervals where significant departures from background values are observed; one interval from $\sim 13$ to $10 \mathrm{ka}$, and the second from $\sim 6 \mathrm{ka}$ to the present day.

\section{ACKNOWLEDGMENTS}

We thank Jim Kennett and Jack Baldauf for inviting us to participate in the Santa Barbara Basin Project. We also thank Rick Behl, Jim Gardner, Linda Heusser, and Ruediger Stein for sharing data from Site 893. The reviewers of the original version of this manuscript provided many helpful comments. This research was funded by a Natural Science and Engineering Research Council of Canada (NSERC) postdoctoral fellowship to F. Rack under the Canadian Joint Global Ocean Flux Study (CJGOFS).

\section{REFERENCES}

Agoston, G.A., 1987. Color Theory and Its Application in Art and Design (2nd ed.): Berlin (Springer-Verlag).

Alley, R.B., Meese, D.A., Shuman, C.A., Gow, A.J., Taylor, K.C., Grootes, P.M., White, J.W.C., Ram, M., Waddington, E.D., Mayewski, P.A., and Zielinski, G.A., 1993. Abrupt increase in Greenland snow accumulation at the end of the Younger Dryas event. Nature, 362:527-529.

Balsam, W.L., and Deaton, B.C., 1991. Sediment dispersal in the Atlantic Ocean: evaluation by visible light spectra. Rev. Aquat. Sci., 4:411-447.

Bard, E., Fairbanks, R., Arnold, M., Maurice, P., Duprat, J., Moyes, J., and Duplessy, J.-C., 1989. Sea-level estimates during the last deglaciation based on $\delta^{18} \mathrm{O}$ and accelerator mass spectrometry ${ }^{14} \mathrm{C}$ ages measured in Globigerina bulloides. Quat. Res., 31:381-391.

Bard, E., Hamelin, B., Fairbanks, R.G., and Zindler, A., 1990. Calibration of the ${ }^{14} \mathrm{C}$ time-scale over the past 30,000 years using mass spectrometric $\mathrm{U}$ Th ages from Barbados corals. Nature, 345:405-410.

Barranco, F.T., Jr., Balsam, W.L., and Deaton, B.C., 1989. Quantitative reassessment of brick red lutites: evidence from reflectance spectrophotometry. Mar. Geol., 89:299-314.

Berelson, W.M., Hammond, D.E., and Johnson, K.S., 1987. Benthic fluxes and the cycling of biogenic silica and carbon in two southern California borderland basins. Geochim. Cosmochim. Acta, 51:1345-1363.

Brandsma, D., Lund, S.P., and Henyey, T.L., 1989. Paleomagnetism of Late Quaternary marine sediments from sediments from Santa Catalina Basin, California Continental Borderland. J. Geophys. Res., 94:547-564.

Charles, C.D., Rind, D., Jouzel, J., Koster, R.D., and Fairbanks, R.G., 1994. Glacial-interglacial changes in moisture sources for Greenland: influences on the ice core record of climate. Science, 263:508-511.

COHMAP Members, 1988. Climatic changes of the last 18,000 years: observations and model simulations. Science, 241:1043-1052.
Dansgaard, W., Johnsen, S.J., Clausen, H.B., Dahl-Jensen, D., Gundestrup, N.S., Hammer, C.U., Hvidberg, C.S., Steffensen, J.P., Sveinbjörnsdottir, A.E., Jouzel, J., and Bond, G., 1993. Evidence for general instability of past climate from a 250-kyr ice-core record. Nature, 364:218-220.

Deaton, B.C., and Balsam, W.L., 1991. Visible spectroscopy: a rapid method for determining hematite and goethite concentrations in geological materials. J. Sediment. Petrol., 61:628-632.

Drake, D.E., Kolpack, R.L., and Fischer, P.J., 1972. Sediment transport on the Santa Barbara-Oxnard shelf, Santa Barbara Channel, California. In Swift, D.J.P., Duane, D.B., and Pilkey, O.H. (Eds.), Shelf Sediment Transport: Process and Pattern: Stroudsburg, PA (Dowden, Hutchinson, and Ross), 307-331.

Emery, K.O., and Hülsemann, J., 1962. The relationships of sediments, life and water in a marine basin. Deep-Sea Res. Part A, 8:165-180.

Fairbanks, R.G., 1989. A 17,000-year glacio-eustatic sea level record: influence of glacial melting rates on the Younger Dryas event and deep-ocean circulation. Nature, 342:637-642.

Fleischer, P., 1972. Mineralogy and sedimentation history, Santa Barbara Basin, California. J. Sediment. Petrol., 42:49-58.

Gallup, C.D., Edwards, R.L., and Johnson, R.G., 1994. The timing of high sea levels over the past 200,000 years. Science, 263:796-800.

Gorsline, D.S., Kolpack, R.L., Karl, H.A., Drake, D.E., Fleischer, P., Thornton, S.E., Schwalbach, J.R., and Savrda, C.E., 1984. Studies of finegrained sediment transport processes and products in the California Continental Borderland. In Stow, D.A.V., and Piper, D.J.W. (Eds.), Finegrained Sediments: Deep-water Processes and Facies. Geol. Soc. Spec. Publ. London, 15:375-415.

Greenland Ice-core Project (GRIP) Members, 1993. Climate instability during the last interglacial period recorded in the GRIP ice core. Nature, 364:203-207.

Hagelberg, T., Shackleton, N., Pisias, N., and Shipboard Scientific Party, 1992. Development of composite depth sections for Sites 844 through 854. In Mayer, L., Pisias, N., Janecek, T., et al., Proc. ODP, Init. Repts., 138 (Pt. 1): College Station, TX (Ocean Drilling Program), 79-85.

Hagelberg, T.K., Pisias, N.G., Shackleton, N.J., Mix, A.C., and Harris, S., 1995. Refinement of a high-resolution, continuous sedimentary section for studying Equatorial Pacific Ocean paleoceanography, Leg 138. In Pisias, N.G., Mayer, L.A., Janecek, T.R., Palmer-Julson, A., and van Andel, T.H. (Eds.), Proc. ODP, Sci Results, 138: College Station, TX (Ocean Drilling Program), 31-46.

Heusser, C.J., Heusser, L.E., and Peteet, D.M., 1985. Late Quaternary climatic change on the American North Pacific coast. Nature, 315:485-487.

Heusser, C.J., Heusser, L.E., and Streeter, S.S., 1980. Quaternary temperatures and precipitation for the north-west coast of North America. Nature, 286:702-704.

Heusser, L.E., 1978. Pollen in Santa Barbara Basin, California: a 12,000 year record. Geol. Soc. Am. Bull., 89:673-678.

1988. Pollen distribution in marine sediments on the continental margin off Northern California. Mar. Geol., 80:131-147.

Imbrie, J., Hays, J.D., Martinson, D.G., McIntyre, A., Mix, A.C., Morley, J.J., Pisias, N.G., Prell, W.L., and Shackleton, N.J., 1984. The orbital theory of Pleistocene climate: support from a revised chronology of the marine $\delta^{18} \mathrm{O}$ record. In Berger, A., Imbrie, J., Hays, J., Kukla, G., and Saltzman, B. (Eds.), Milankovitch and Climate (Pt. 1): Dordrecht (D. Reidel), 269-305.

Jahnke, R.A., 1990. Early diagenesis and recycling of biogenic debris at the seafloor, Santa Monica Basin, California. J. Mar. Res., 48:413-436.

Karlin, R., 1990a. Magnetic diagenesis in marine sediments from the Oregon Continental Margin. J. Geophys. Res., 95:4405-4419.

, 1990b. Magnetite mineral diagenesis in suboxic sediments at Bettis Site W-N, NE Pacific Ocean. J. Geophys. Res., 95:4421-4436.

Karlin, R., and Levi, S., 1983. Diagenesis of magnetic minerals in Recent hemipelagic sediments. Nature, 303:327-330.

- 1985. Geochemical and sedimentological control of the magnetic properties of hemipelagic sediments. J. Geophys. Res., 90:10373-10392.

Kennett, J.P., Baldauf, J.G., et al., 1994. Proc. ODP, Init. Repts., 146 (Pt. 2): College Station, TX (Ocean Drilling Program).

Kutzbach, J.E., and Ruddiman, W.F., 1993. Model description, external forcing, and surface boundary conditions. In Wright, H.E., Jr., Kutzbach, J.E., Webb, T., Jr., Ruddiman, W.F., Street-Perrott, F.A., and Bartlein, P.J. (Eds.), Global Climates Since the Last Glacial Maximum: Minneapolis (Univ. Minn. Press), 12-23.

Kutzbach, J.E., and Webb, T., III, 1993. Conceptual basis for understanding Late-Quaternary climates. In Wright, H.E., Jr., Kutzbach, J.E., Webb T., 
Jr., Ruddiman, W.F., Street-Perrott, F.A., and Bartlein, P.J. (Eds.), Global Climates Since the Last Glacial Maximum: Minneapolis (Univ. Minn. Press), 5-11.

Lange, C.B., Berger, W.H., Burke, S.K., Casey, R.E., Schimmelmann, A., Soutar, A., and Weinheimer, A.L., 1987. El Niño in Santa Barbara basin: diatom, radiolarian, and foraminiferan responses to the "1983 El Niño" event. Mar. Geol., 78:153-160.

Lange, C.B., Burke, S.K., and Berger, W.H., 1990. Biological production off Southern California is linked to climatic change. Clim. Change, 16:319329.

Leslie, B.W., Hammond, D.E., Berelson, W.M., and Lund, S.P., 1990a. Diagenesis in anoxic sediments from the California continental borderland and its influence on iron, sulfur, and magnetite behavior. J. Geophys. Res., 95:4453-4470.

Leslie, B.W., Lund S.P., and Hammond, D.E., 1990b. Rock magnetic evidence for the dissolution and authigenic growth of magnetic minerals within anoxic marine sediments of the California Continental Borderland. J. Geophys. Res., 95:4437-4452.

Lund, S.P., Gorsline, D.S., and Henyey, T.L., 1992. Rock magnetic characteristics of surficial marine sediments from the California Continental Borderland. Earth Planet. Sci. Lett., 108:93-107.

Martinson, D.G., Pisias, N.G., Hays, J.D., Imbrie, J., Moore, T.C., Jr., and Shackleton, N.J., 1987. Age dating and the orbital theory of the ice ages: development of a high-resolution 0 to 300,000 -year chronostratigraphy. Quat. Res., 27:1-29.

Mathewes, R.W., and Heusser, L.E., 1981. A 12,000 year palynological record of temperature and precipitation trends in southwestern British Columbia. Can. J. Bot., 59:707-710.

Mayer, L.A., Jansen, E., Backman, J., and Takayama, T., 1993. Climatic cyclicity at Site 806: the GRAPE record. In Berger, W.H., Kroenke, L.W., Mayer, L.A., et al., Proc. ODP, Sci. Results, 130: College Station, TX (Ocean Drilling Program), 623-639.

Mayewski, P.A., Meeker, L.D., Whitlow, S., Twickler, M.S., Morrison, M.C., Bloomfield, P., Bond, G.C., Alley, R.B., Gow, A.J., Grootes, P.M., Meese, D.A., Ram, M., Taylor, K.C., and Wumkes, W., 1994. Changes in atmospheric circulation and ocean ice cover over the North Atlantic during the last 41,000 years. Science, 263:1747-1751.

Mix, A.C., Harris, S.E., and Janecek, T.R., 1995. Estimating lithology from nonintrusive reflectance spectra: Leg 138. In Pisias, N.G., Mayer, L.A., Janecek, T.R., Palmer-Julson, A., and van Andel, T.H. (Eds.), Proc. ODP, Sci. Results, 138: College Station, TX (Ocean Drilling Program), 413-427.

Mix, A.C., Rugh, W., Pisias, N.G., Veirs, S., Leg 138 Shipboard Sedimentologists (Hagelberg, T., Hovan, S., Kemp, A., Leinen, M., Levitan, M., Ravelo, C.), and Leg 138 Scientific Party, 1992. Color reflectance spectroscopy: a tool for rapid characterization of deep-sea sediments. In Mayer, L., Pisias, N., Janecek, T., et al., Proc. ODP, Init. Repts., 138 (Pt. 1): College Station, TX (Ocean Drilling Program), 67-77.

Mountain, G.S., Miller, K.G., Blum, P., et al., 1994. Proc. ODP, Init. Repts., 150: College Station, TX (Ocean Drilling Program).

Nardin, T.R., Osborne, R.H., Bottjer, D.J., and Scheidemann, R.C., 1981. Holocene sea level curves from Santa Monica Shelf, California continental borderland. Science, 213:331-333.

Peltier, W.R., 1994. Ice age paleotopography. Science, 265:195-201.

Reimers, C.E., Lange, C.B., Tabak, M., and Bernhard, J.M., 1990. Seasonal spillover and varve formation in the Santa Barbara Basin, California. Limnol. Oceanogr., 35:1577-1585.

Rypins, S., Reneau, S.L., Byrne, R., and Montgomery, D.R., 1989. Palynologic and geomorphic evidence for environmental change during the
Pleistocene-Holocene transition at Point Reyes Peninsula, central coastal California. Quat. Res., 32:72-87.

Saltzman, B., and Verbitsky, M., 1994. $\mathrm{CO}_{2}$ and glacial cycles. Nature, $367: 419$.

Schimmelmann, A., and Kastner, M., 1993. Evolutionary changes over the last 1000 years of reduced sulfur phases and organic carbon in varved sediments of the Santa Barbara Basin, California. Geochim. Cosmochim. Acta, 57:67-78.

Schimmelmann, A., Lange, C.B., and Berger, W.H., 1990. Climatically controlled marker layers in Santa Barbara basin sediments, and fine-scale core-to-core correlation. Limnol. Oceanogr., 35:165-173.

Schimmelmann, A., Lange, C.B., Berger, W.H., Simon, A., Burke, S.K., and Dunbar, R.B., 1992. Extreme climatic conditions recorded in Santa Barbara Basin laminated sediments: the 1835-1840 Macoma event. Mar. Geol., 106:279-299.

Schwalbach, J.R., and Gorsline, D.S., 1985. Holocene sediment budgets for the basins of the California Continental Borderland. J. Sediment. Petrol., $55: 829-842$

Shackleton, N.J., Crowhurst, S., Hagelberg, T., Pisias, N.G., and Schneider, D.A., 1995. A new late Neogene time scale: application to Leg 138 sites. In Pisias, N.G., Mayer, L.A., Janecek, T.R., Palmer-Julson, A., and van Andel, T.H. (Eds.), Proc. ODP, Sci. Results, 138: College Station, TX (Ocean Drilling Program), 73-101.

Shackleton, N.J., and Shipboard Scientific Party, 1992. Sedimentation rates: toward a GRAPE density stratigraphy for Leg 138 carbonate sections. In Mayer, L., Pisias, N., Janecek, T., et al., Proc. ODP, Init. Repts., 138 (Pt. 1): College Station, TX (Ocean Drilling Program), 87-91.

Soutar, A., and Crill, P.A., 1977. Sedimentation and climatic patterns in the Santa Barbara Basin during the 19th and 20th centuries. Geol. Soc. Am. Bull., 88:1161-1172.

Thompson, R.S., Whitlock, C., Bartlein, P.J., Harrison, S.P., and Spaulding, W.G., 1993. Climatic changes in the western United States since 18,000 yr B.P. In Wright, H.E., Jr., Kutzbach, J.E., Webb, T., Jr., Ruddiman, W.F., Street-Perrott, F.A., and Bartlein, P.J. (Eds.), Global Climates Since the Last Glacial Maximum: Minneapolis (Univ. Minn. Press), 468513.

Thornton, S.E., 1981. Suspended sediment transport in surface waters of the California Current off southern California: 1977-78 floods. Geo-Mar. Lett., 1:23-28.

, 1984. Basin model for hemipelagic sedimentation in a tectonically active continental margin: Santa Barbara Basin, California continental borderland. In Stow, D.A.V., and Piper, D.J.W. (Eds.), Finegrained Sediments: Deep-water Processes and Facies. Geol. Soc. Spec. Publ. London, 15:377-394.

1986. Origin of mass flow sedimentary structures in hemipelagic basin deposits: Santa Barbara basin, California Borderland. Geo-Mar. Lett., 6:15-19.

Tushingham, A.M., and Peltier, W.R., 1991. ICE-3G: a new global model of late Pleistocene deglaciation based upon geophysical predictions of postglacial relative sea level change. J. Geophys. Res., 96:4497-4523.

Wyszecki, G., and Stiles, W.S., 1982. Color Science: Concepts and Methods, Quantitative Data and Formulae (2nd ed.): New York (Wiley).

\footnotetext{
Date of initial receipt: 26 August 1994

Date of acceptance: 23 March 1995

Ms 146SR-287
} 
F.R. RACK, R.B. MERRILL

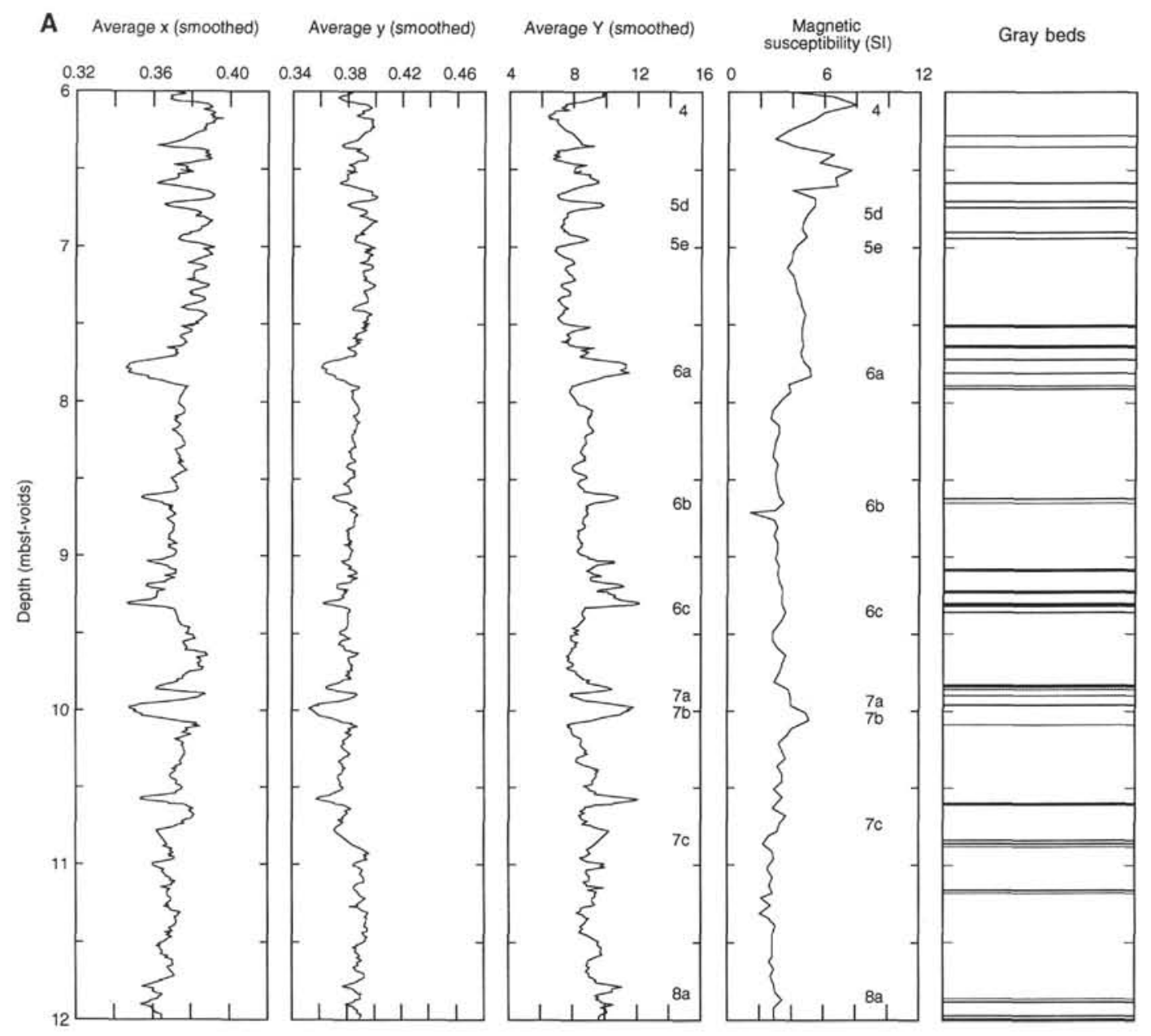

Figure 9. Summary plots of smoothed digital color (CIE $1931[\mathrm{x}, \mathrm{y}, \mathrm{Y}]$ tristimulus values) and magnetic susceptibility data for the interval from 6 to $12 \mathrm{mbsf}$. A. Hole 893 A. B. Hole 893 B. 


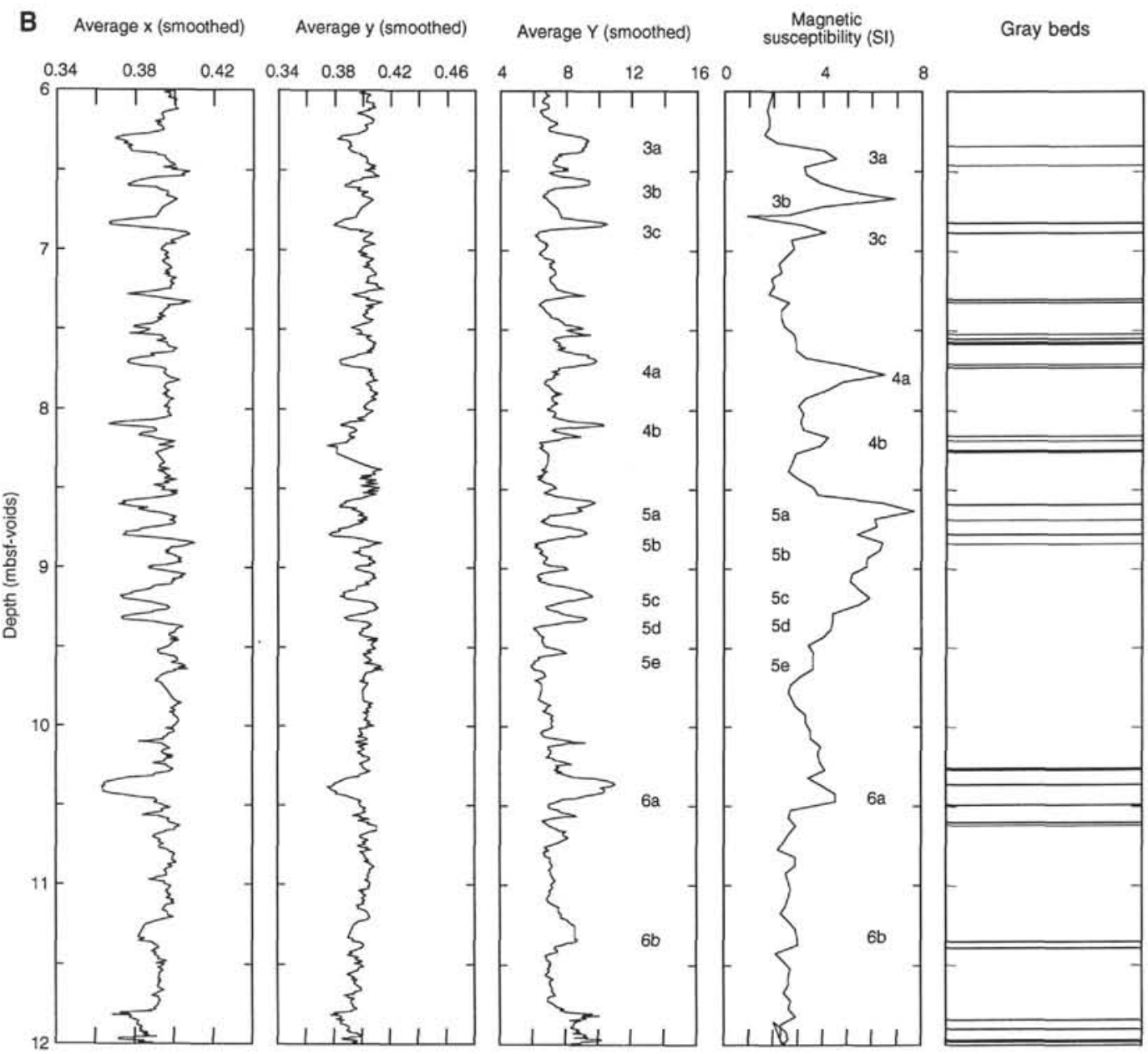

Figure 9 (continued). 
F.R. RACK, R.B. MERRILL

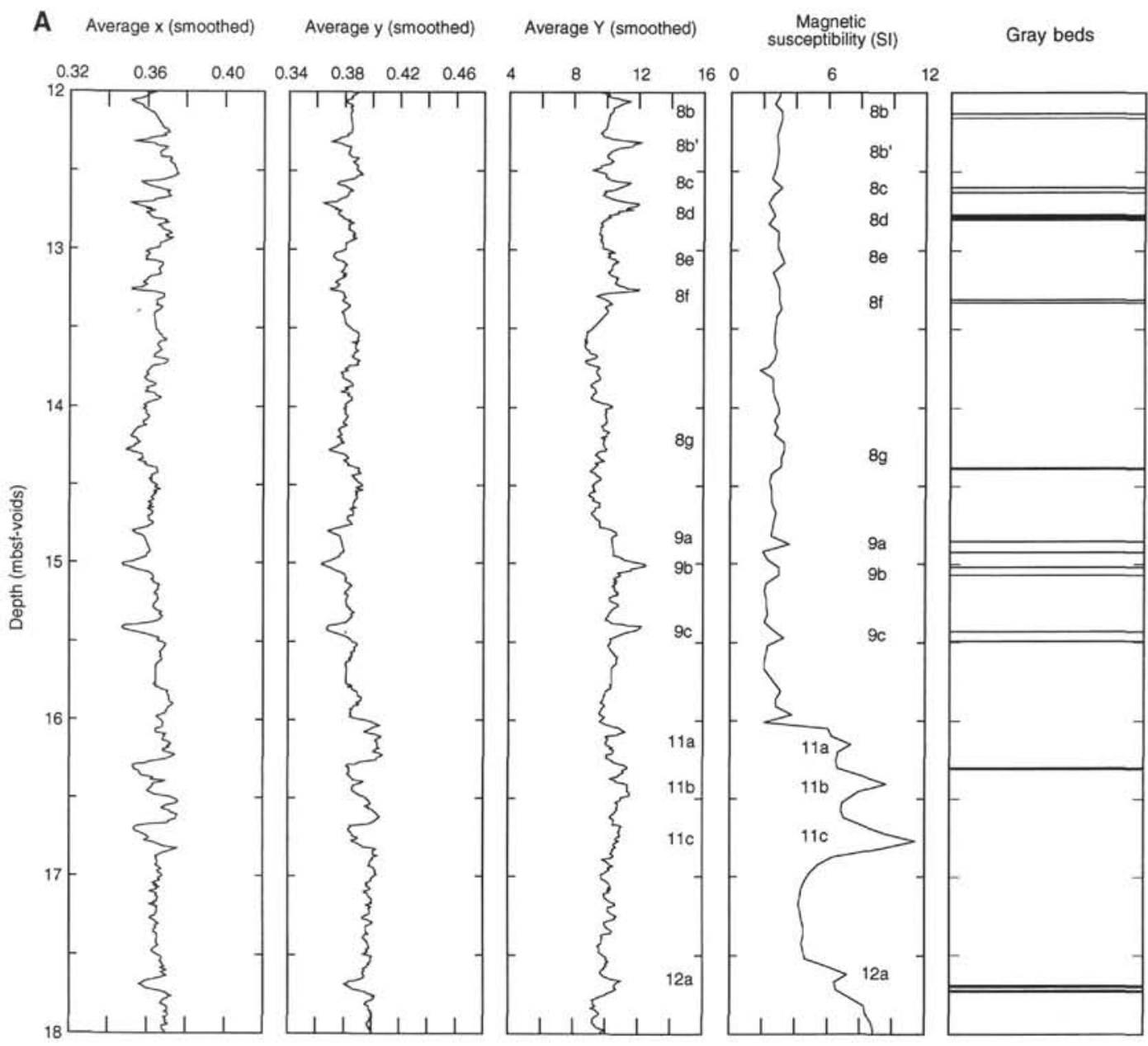

Figure 10. Summary plots of smoothed digital color (CIE 1931 [x, y, Y] tristimulus values) and magnetic susceptibility data for the interval from I2 to 18 mbsf. A. Hole 893A. B. Hole 893B. 
INTERHOLE CORRELATIONS AT SITE 893

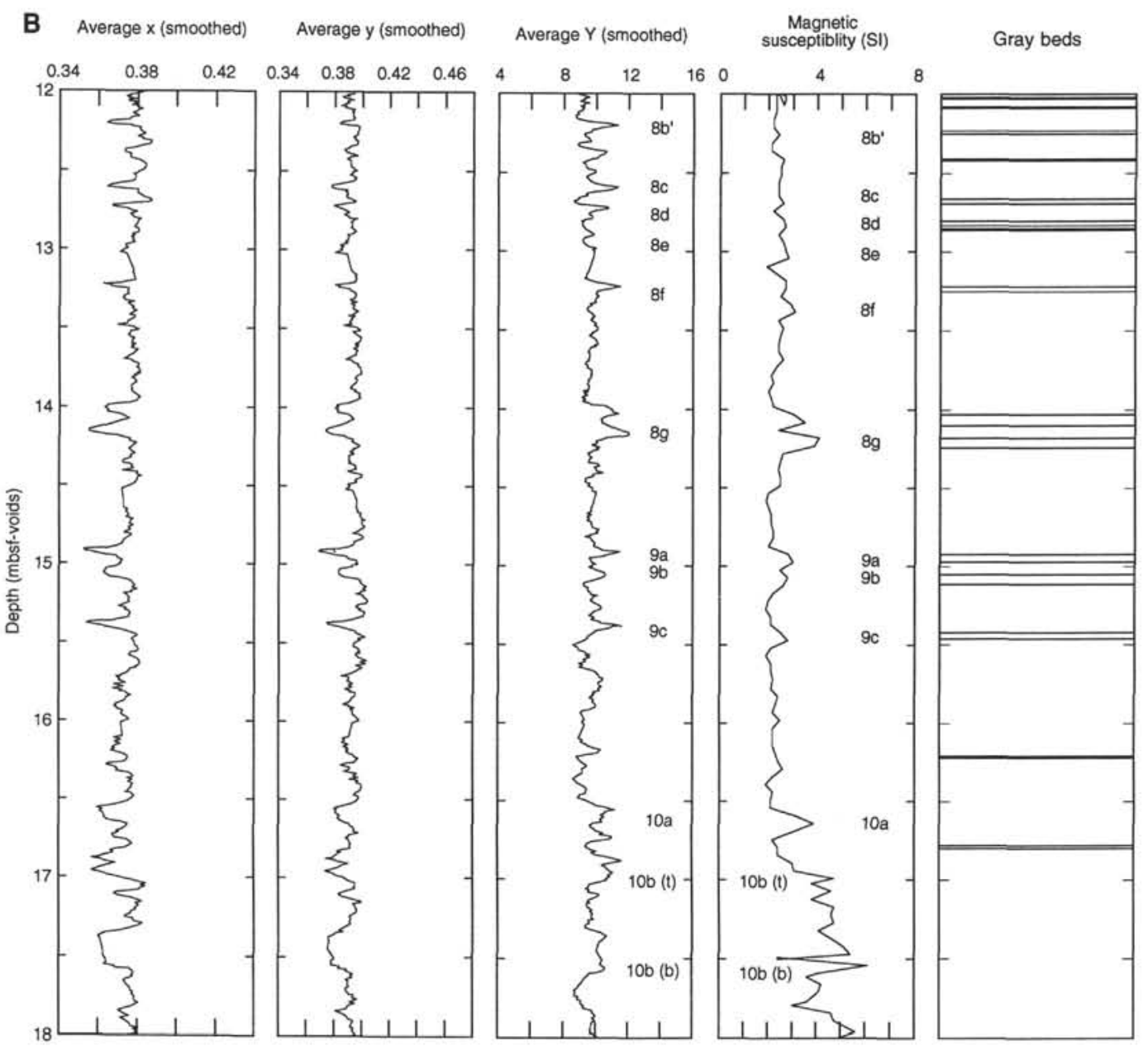

Figure 10 (continued). 
F.R. RACK, R.B. MERRILL

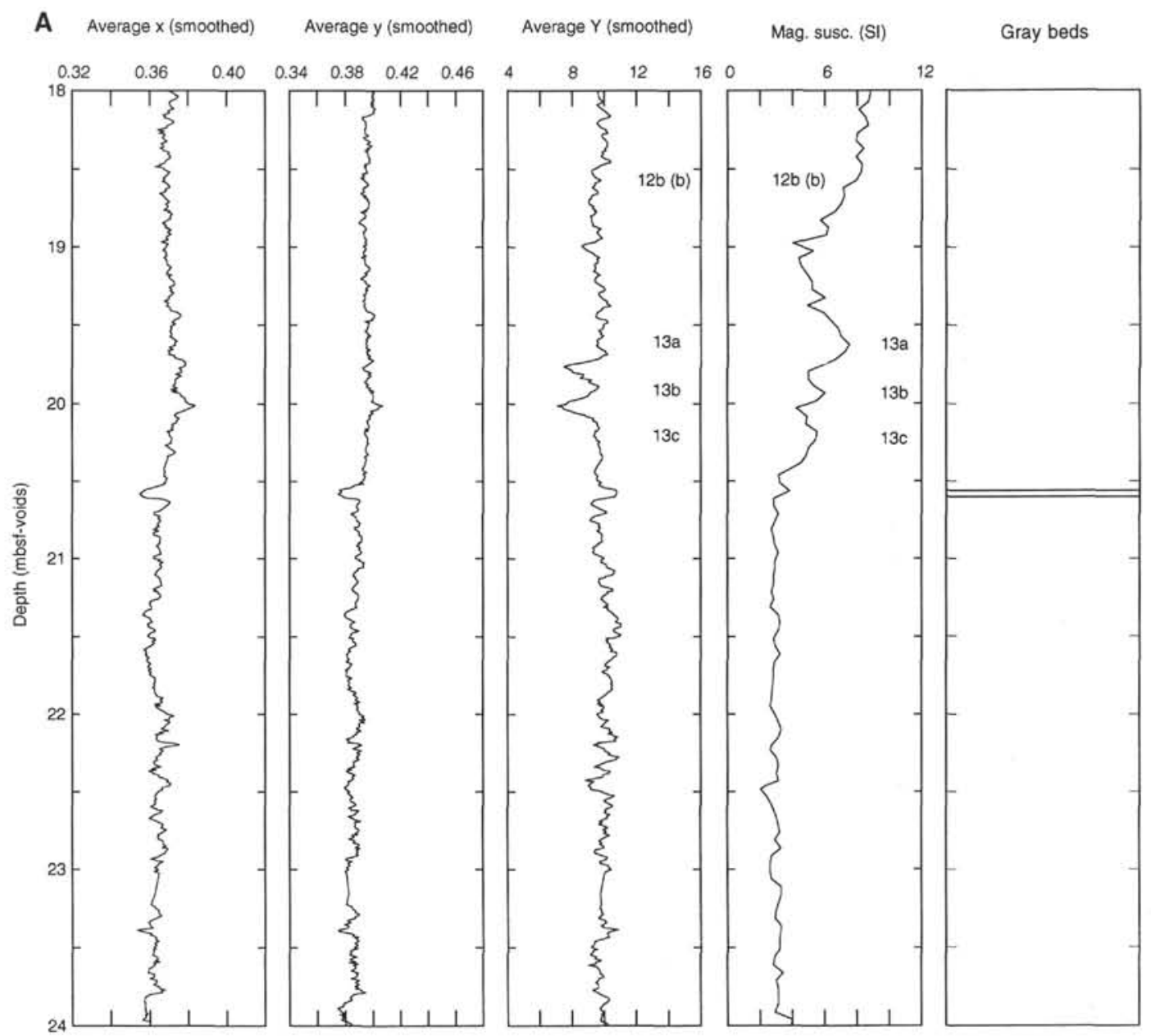

Figure 11. Summary plots of smoothed digital color (CIE 1931 [x, y, Y] tristimulus values) and magnetic susceptibility data for the interval from 18 to 24 mbsf. A. Hole 893A. B. Hole 893B. 


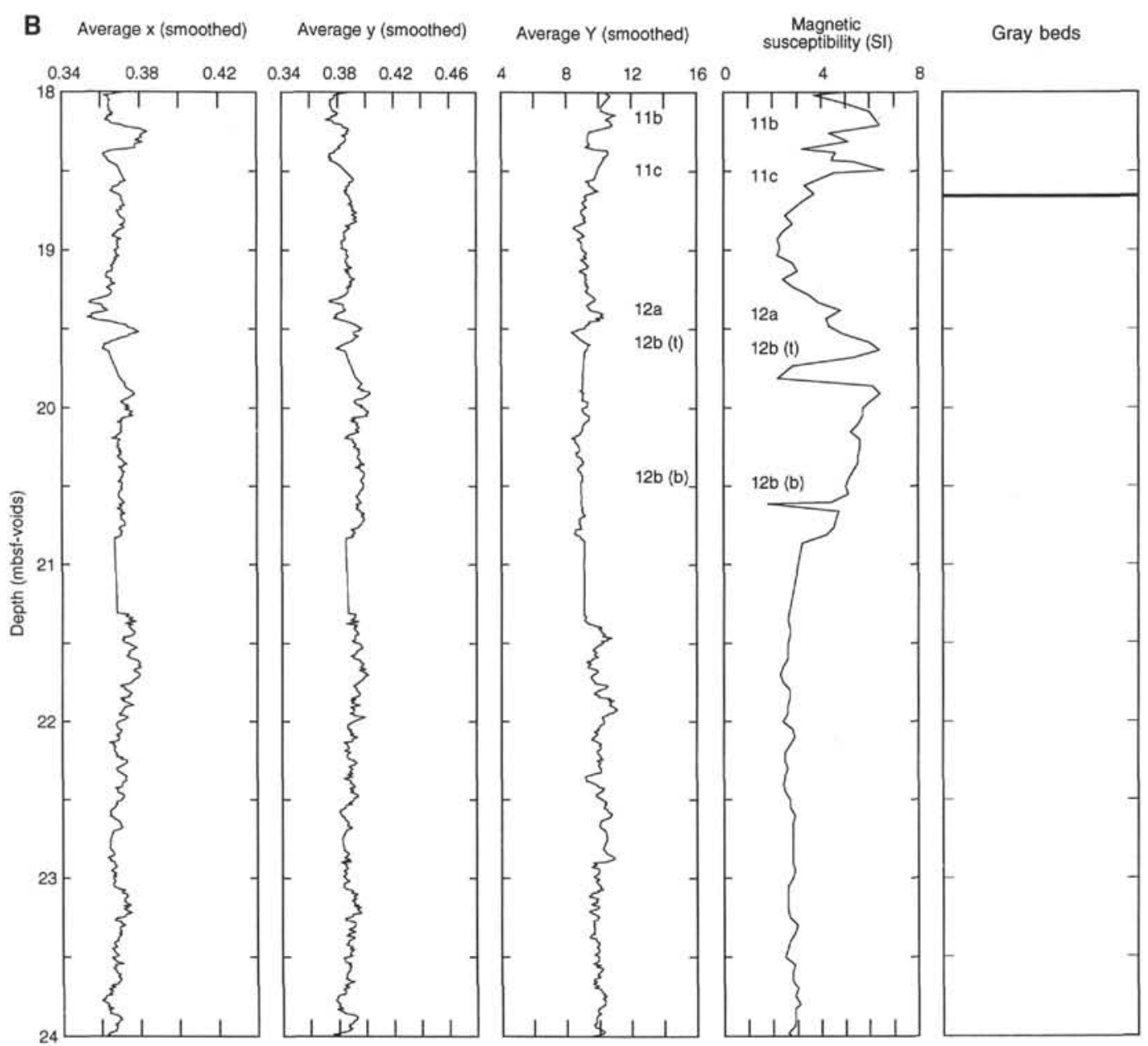

Figure 11 (continued). 


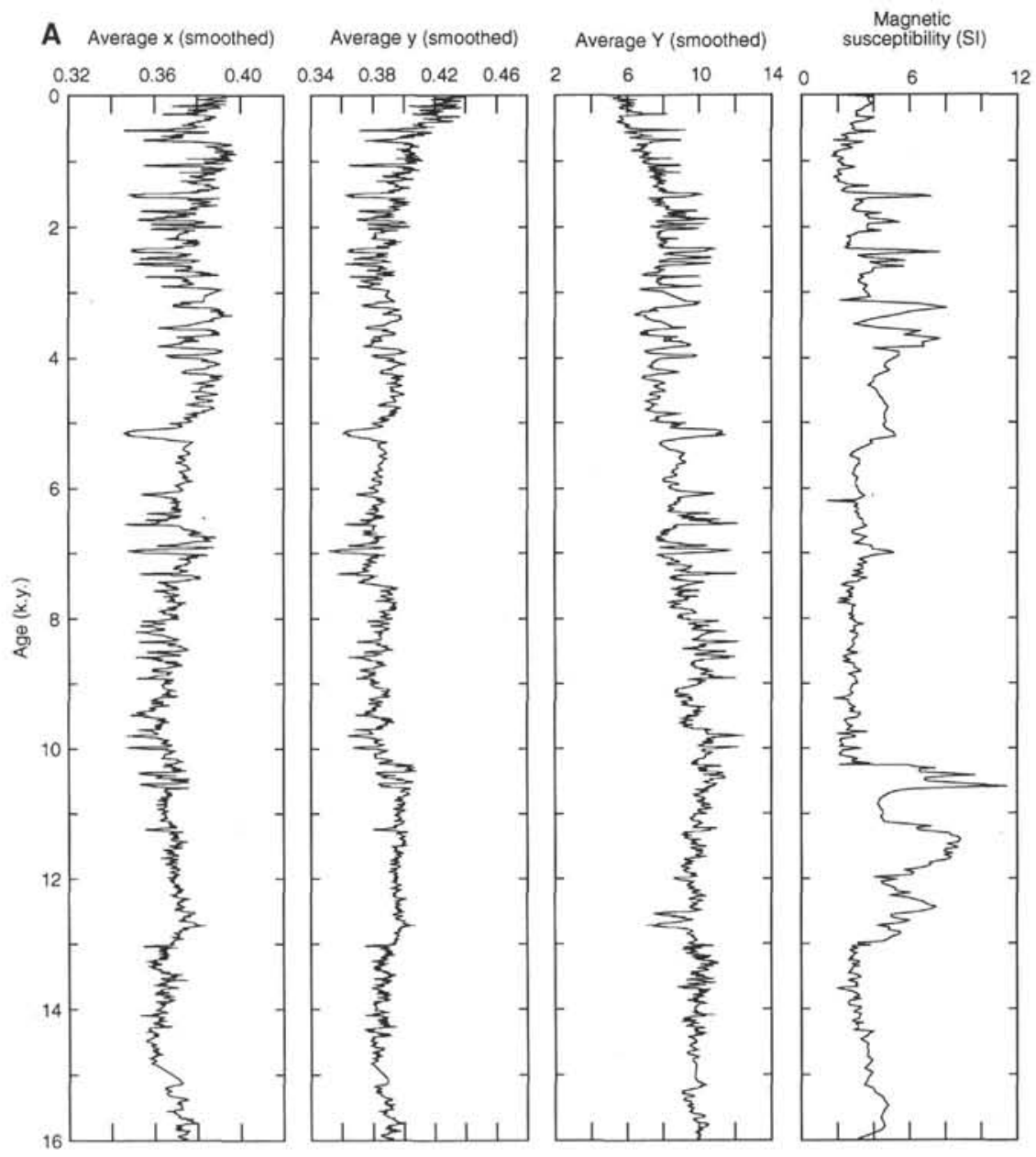

Figure 12. Summary plots of smoothed digital color (CIE 1931 [x, y, Y] tristimulus values) and magnetic susceptibility data for the past $16 \mathrm{ka}$, from the present day to just after the Last Glacial Maximum. 


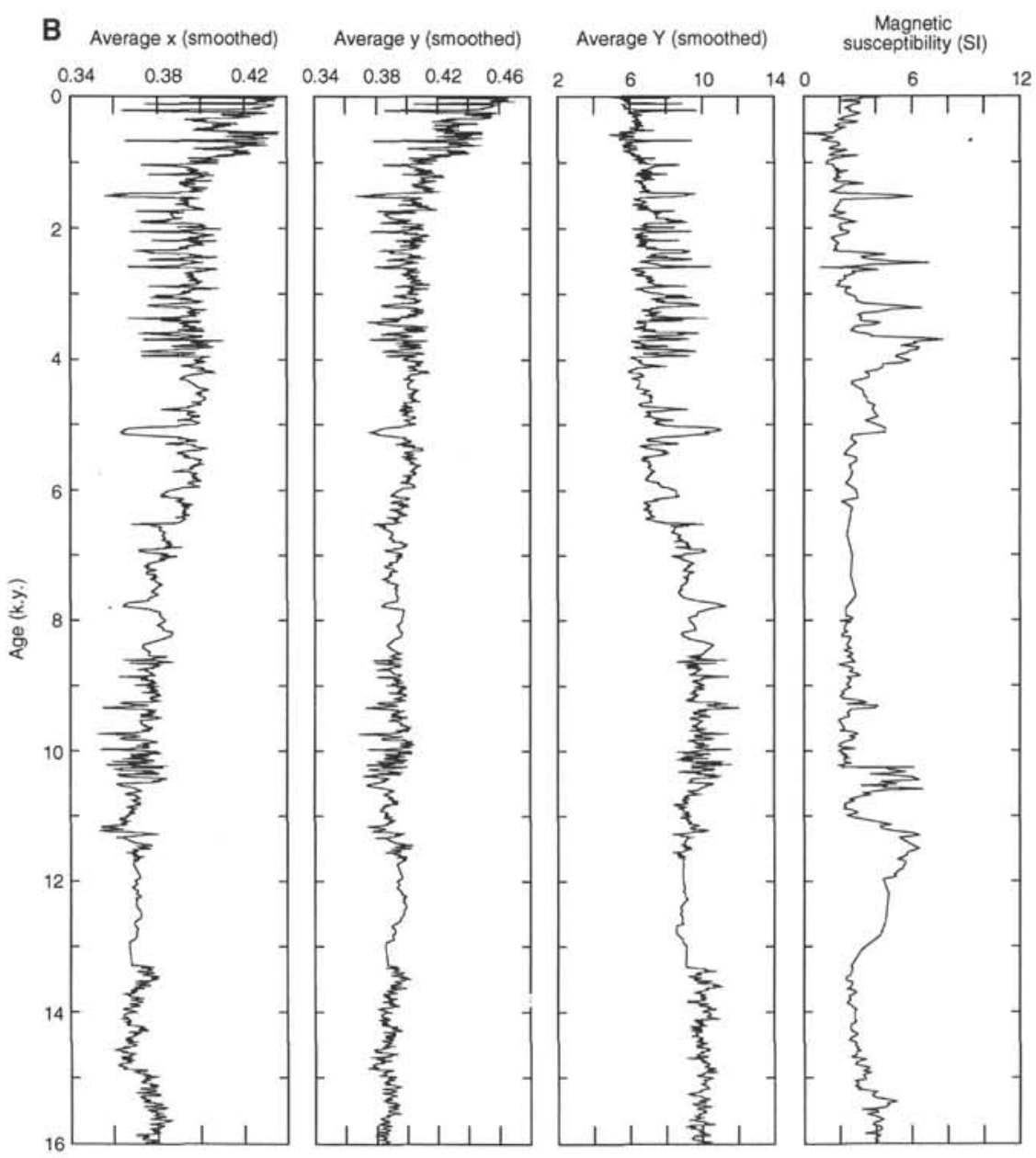

Figure 12 (continued).

Table 4. Splice intervals used to develop a composite section for Site 893.

\begin{tabular}{ccccccc}
\hline Hole & $\begin{array}{c}\text { Hole 893B V depth } \\
\text { (mbsf) }\end{array}$ & $\begin{array}{c}\text { Thickness } \\
(\mathrm{m})\end{array}$ & $\begin{array}{c}\text { Hole 893A V depth } \\
\text { (mbsf) }\end{array}$ & $\begin{array}{c}\text { Thickness } \\
(\mathrm{m})\end{array}$ & $\begin{array}{c}\text { Depth } \\
(\mathrm{mcd})\end{array}$ & $\begin{array}{c}\text { Thickness } \\
(\mathrm{m})\end{array}$ \\
\hline 893B & $\mathbf{0 . 0 0 - 1 . 9 8}$ & $\mathbf{1 . 9 8}$ & $0.00-0.95$ & 0.95 & $0.00-1.98$ & 1.98 \\
893A & $1.98-\mathbf{7 . 3 2}$ & 5.34 & $\mathbf{0 . 9 5 - 5 . 7 0}$ & $\mathbf{4 . 7 5}$ & $1.98-6.73$ & 4.75 \\
893B & $\mathbf{7 . 3 2 - 1 1 . 4 2}$ & $\mathbf{4 . 1 0}$ & $5.70-8.86$ & 3.16 & $6.73-10.83$ & 4.10 \\
893A & $\mathbf{1 1 . 4 2 - 1 3 . 1 8}$ & 1.76 & $\mathbf{8 . 8 6 - 1 3 . 1 4}$ & $\mathbf{4 . 2 8}$ & $10.83-15.11$ & 4.28 \\
893B & $\mathbf{1 3 . 1 8 - 1 9 . 2 8}$ & $\mathbf{6 . 1 0}$ & $13.14-17.52$ & 4.38 & $15.11-21.21$ & 6.10 \\
893A & $19.28-23.55$ & 4.27 & $\mathbf{1 7 . 5 2 - 2 1 . 7 1}$ & $\mathbf{4 . 1 9}$ & $21.21-25.40$ & 4.19 \\
893B & $\mathbf{2 3 . 5 5 - 3 0 . 0 3}$ & $\mathbf{6 . 4 8}$ & $21.71-28.61$ & 6.90 & $25.40-31.88$ & 6.48 \\
\hline
\end{tabular}

Notes: $\mathrm{V}$ depth $=$ void-corrected depth. The approximate age range of the composite section is 0 to $16 \mathrm{ka}$. All of spliced intervals are taken from within individual cores, thus avoiding core breaks. The final spliced interval extends to near the base of Core $146-893 \mathrm{~B}-4 \mathrm{H}$. The values in bold identify the spliced intervals from each hole that were used to construct a composite section for Site 893, med = meters composite depth. 


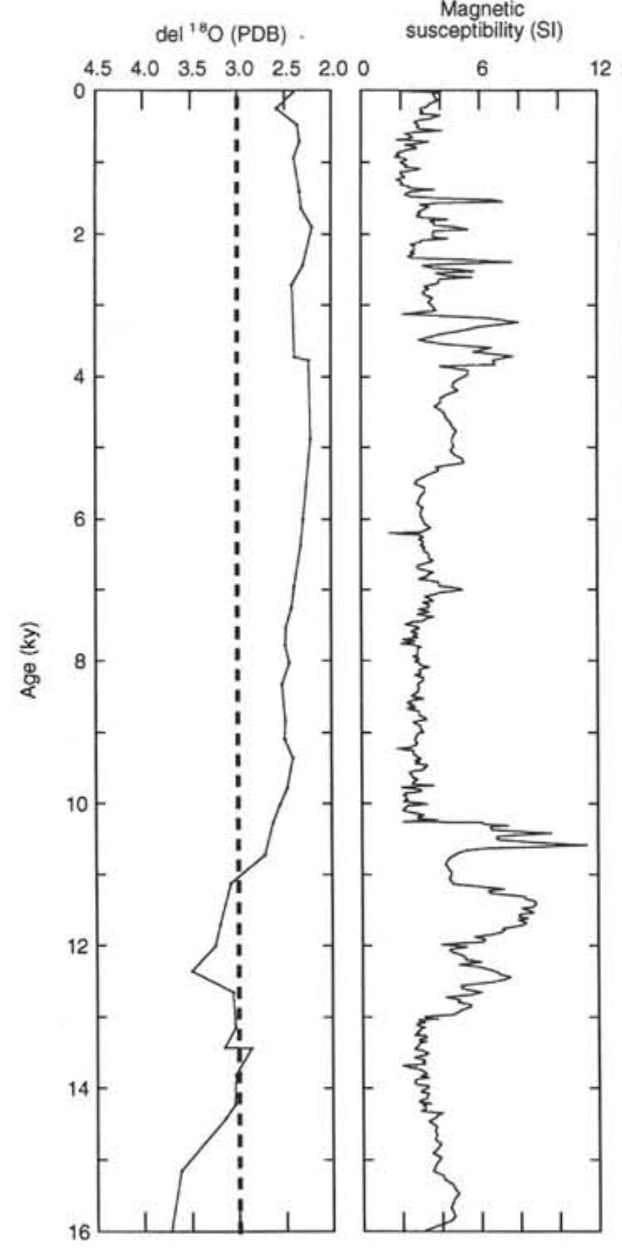

Hole 893A
$Y$ (smoothed) $\begin{array}{llll}6 & 10 & 14\end{array}$

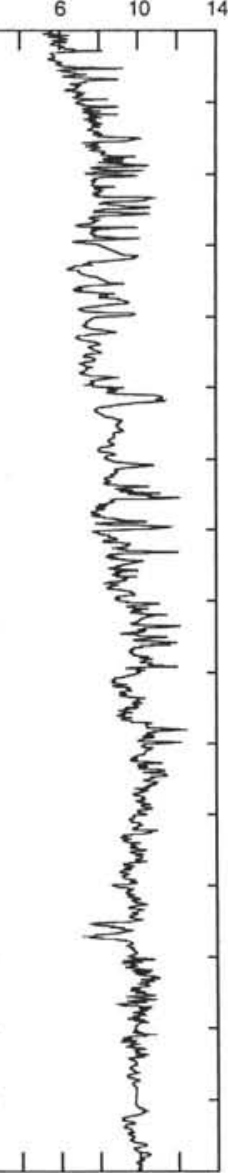

$\xi$
Gray beds

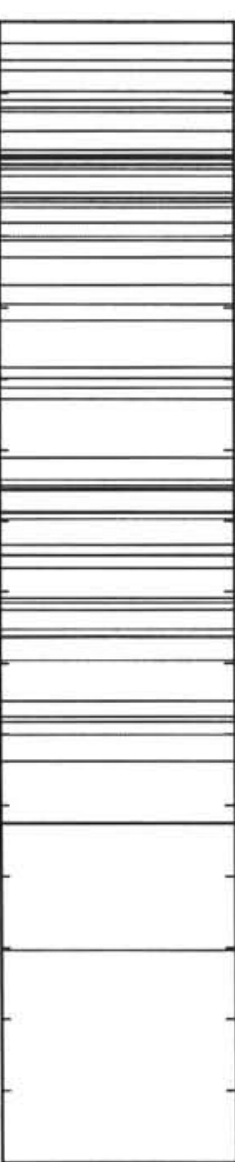

\section{.}

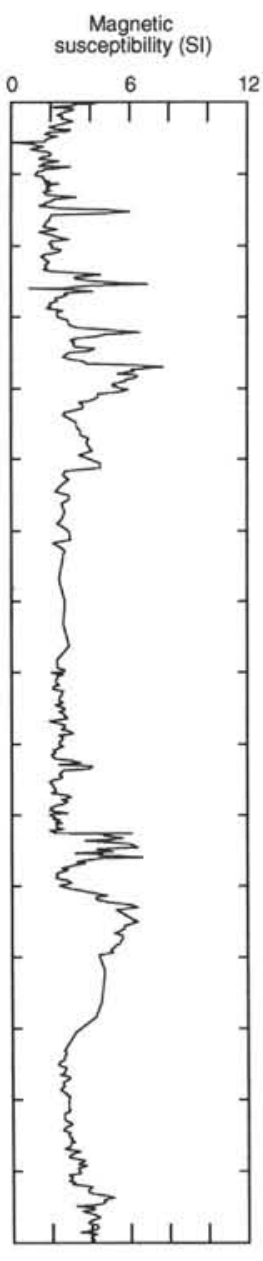

Hole 893B

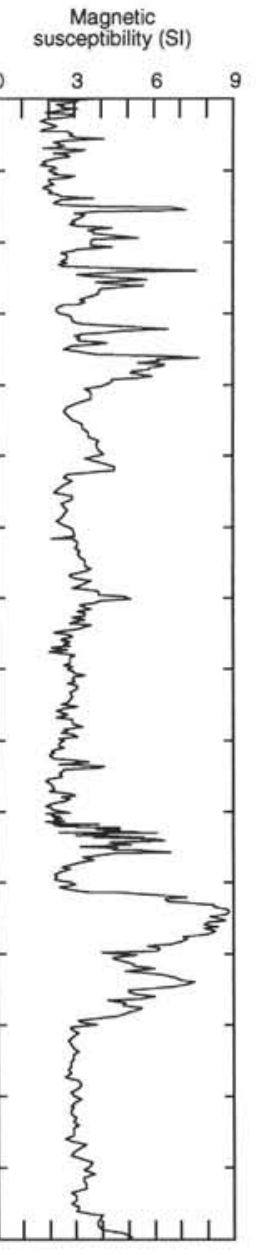

893 composite
Ice mass $\left(\times 10^{19} \mathrm{~kg}\right)$

$8^{18} \mathrm{O}$

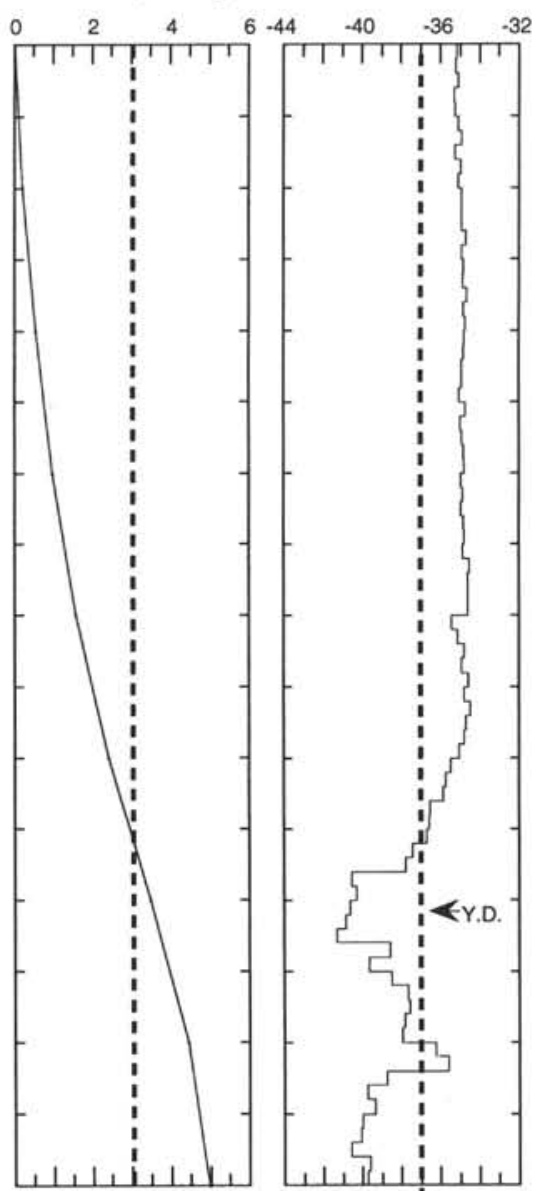

GRIP ice core

Figure 13. Split-core magnetic susceptibility measurements in Holes 893A and 893B and Site 893 composite magnetic susceptibility record. Also shown are (1) the oxygen isotope stratigraphy of Kennett (this volume); (2) the luminance values measured on Hole 893A cores; (3) the positions of gray beds in Hole 893A; (4) ice mass deduced from the SPECMAP oxygen isotope stack (Imbrie, et al., 1984; Saltzman and Verbitsky, 1994); and (5) $\delta^{18} \mathrm{O}$ determinations from the GRIP ice core (after Dansgaard et al., 1993); the GRIP $\delta^{18} \mathrm{O}$ curve has been annotated to identify the Younger Dryas (Y.D.) period. 